\title{
NEW WEST INDIAN CARABIDE, WITH A LIST OF THE CUBAN SPECIES ${ }^{12}$
}

By P. J. DARLington, JR.

Museum of Comparative Zoölogy, Cambridge, Mass.

The purpose of the present paper is two-fold: first, to describe a number of new Carabidæ which have come to hand during several years of sporadic work on the West Indian fauna, and second, to give a complete list of the species now known from Cuba. Eventually I plan to publish a revision of all the Carabidæ of the West Indies. However, this will have to await the acquisition of much more material than is now available, and I think in the meantime a Cuban list (which adds very little to the length of this paper) will be useful not only to collectors on the island, but to any coleopterists in the United States who feel a responsibility for knowing something about the Cuban fauna.

The order of genera in the list is approximately that of the Junk Catalogue. The Cuban species are numbered consecutively; species from other islands are interpolated without numbers. Of the 134 species here listed from Cuba (about twice the number previously known) I have seen Cuban specimens of 128 . The 6 which I have not seen are noted in the list. The synonymy which I have cited is practically limited to names used for actual Cuban specimens by earlier writers, of whom the chief have been the following:

1. Jacquelin-Duval, 1857, in Ramon de la Sagra's Histoire physique, politique et naturelle de l'Jle de Cuba (French Ed.), Animaux Articulés [Vol. 7], pp. 6-24 (Carabidæ) .

${ }^{1}$ Publication aided by a grant from the Museum of Comparative Zoology.

2Including as a supplement a new Masoreus (Aephnidius) by A. J. Mutchler. 
2. Chevrolat, 1863, Ann. Soc. Ent. France (4) 3, pp. 186199.

3. Gundlach, 1891, Contribución á la Entomologia Cubana, Vol. 3, part 5, pp. 12-33 (sometimes cited as of An. Acad. Cien. Habana).

4. Leng \& Mutchler, 1914, Bull. American Mus. Nat. Hist. 33, pp. 393-397.

5. Leng \& Mutchler, 1917, Ibid. 37, pp. 194-195.

The material I have examined includes the collections of the Museum of Comparative Zoölogy (containing Cuban specimens collected by me in 1926 and 1929, on trips made possible by grants from the Atkins Foundation of Harvard University), the United States National Museum, the American Museum of Natural History, and the Philadelphia Academy of Sciences (Poey material from Cuba); collections submitted by Prof. Stuart T. Danforth (Puerto Rico), Mr. S. C. Bruner of the Estación Experimental Agronómica and Mr. M. L. Jaume (Cuba) ; and smaller lots of specimens from other sources. My thanks are due to all of these persons and to the curators of the museums mentioned. I have also to acknowledge assistance given me by Mr. René Oberthür, Mr. K. G. Blair, Dr. R. Jeannel, Dr. Joseph Bequært, Mr. A. d'Orchymont, Mr. W. S. Blatchley, Mr. A. J. Mutchler, Mr. M. Bänninger, Dr. S. Breuning, and the late Prof. H. F. Wickham, all of whom have either compared specimens with types inaccessible to me, or identified material in special genera, or helped me in other ways.

1. Calosoma (s. s.) splendidum Dej.

2. Calosoma (Callistriga) a. alternans (Fab.)

3. Pachyteles gyllenhali (Dej.) pallida (Chev.)

4. Scarites alternans Chd.

5. Scarites subterraneus Fab. (varities)

6. Clivina dentipes Dej.

Clivina addita $n$. sp.

Of average form for Clivina of dentipes group, slightly depressed; black, appendages piceous. Head with clypeus 
bi-emarginate each side, but less deeply so than in dentipes; front with longitudinal and transverse lines as in dentipes, with small median puncture, otherwise impunctate; antennæ not reaching to basal angles of prothorax. Prothorax by measurement very slightly wider than long; moderately convex; posterior margin basal; posterior angles not conspicuous; disk not punctate, with usual impressed lines and also with fine, irregular, well separated transverse lines. Elytra not margined at base, rather deeply striate, striæ moderately punctate; eighth stria not continued above humerus; third stria five-punctate. Front femur with small, rounded-obtuse tooth on lower posterior edge near apex; front tibia tridentate externally above terminal digit, finely bicanaliculate on anterior face near apex, inconspicuously toothed near middle of posterior face; front trochanters not angulately prominent; middle tibia spurred externally near apex; paronychium short or absent in unique type, but probably long in fresh specimens. Lower surface without unusual punctuation; last ventral with inner pair of punctures twice as far apart as distance between them and outer punctures. Length $8 \mathrm{~mm}$.

Holotype (Museum of Comparative Zoölogy no. 19489) from Mayagüez, Puerto Rico, F. Mara, sent by S. T. Danforth; unique.

In Putzeys' revision of Clivina (Ann. Soc. Ent. Belgique 10,1866 ) this species would belong in group 24 (dentipes etc.), but it will not fit in any of the six sections of that group. It is excluded from the first four sections either by absence of a basal elytral margin or by the small obtuse femoral tooth; from the fifth, by the impunctate abdomen and only slightly and broadly emarginate epistoma; and from the sixth, by the short antennæ. It is at once separable from dentipes, which it somewhat resembles, by the reduced femoral tooth.

7. Clivina cubæ n. sp.

Slender, parallel, slightly depressed; piceous black, appendages and parts of lower surface rufescent. Head with clypeus deeply bi-emarginate each side; front shining, al- 
most impunctate except for a punctiform impression at middle; antennæ reaching about to basal angles of prothorax. Prothorax depressed, almost square, not narrowed in front; anterior angles minutely prominent, posterior angles finely denticulate; impressed lines on disk normal for dentipes group; surface of pronotum very finely punctate. Elytra with striæ moderately impressed and punctate; not margined at base between first and sixth intervals; small tubercle at base of first stria; third stria with five setigerous punctures; sixth and seventh intervals finely carinate at base, sixth joining elytral margin in front of humeral angle. Front femur with a short, obtuse tooth (hardly more than a pronounced sinuation) below near apex; front tibia lightly sulcate above, tridentate externally above terminal digit, with only a very minute tooth near middle of posterior face; front trochanters not angulately prominent; middle tibia with spur on outer side near apex; paronychium about as long as claws. Pro,-, meso-, and metathorax punctate at sides below; abdomen finely but distinctly punctate, especially at sides and on apical segment; prosternum about as in dentipes; last ventral with inner pair of setæ separated by about one and a half times the distance between them and outer setæ. Length 51/2-6 mm.; width $\pm 11 / 2 \mathrm{~mm}$.

Holotype (Museum of Comparative Zoölogy no. 19490) and 10 paratypes from Soledad (near Cienfuegos) Cuba, June and Oct. 31, washed from gravel banks of the Arimao River; 6 paratypes from Cayamas, ${ }^{1}$ Cuba, May 25-June 8, E. A. Schwarz (United States National Museum) ; 1 paratype from Baraguá, Camagüey, Cuba, June 5, L. D. Christenson, at light (U. S. N. M.) .

This species belongs in group 24 (dentipes group) in Putzeys' revision $(l . c$.$) . Within this group it falls in section$ 5 or 6 , resembling only $C$. latimana Putz. and C. punctiventris Putz., both of South America, in ventral punctuation. From latimana, cubæ differs in having the epistoma

${ }^{1}$ The Cayamas from which Schwarz's specimens came is in southwestern Santa Clara, near Yaguaramas ( $C f$. Proc. Ent. Soc. Washington 5, 1903, p. 287). 
not more emarginate than usual at middle; from punctiventris, in having shorter antennæ. A comparison of specimens would probably show other differences. From Clivina dentipes and $C$. addita, the only previously described West Indian species of its group, cubæ is distinguished at once by its smaller size and more extensively punctate lower surface.

8. Clivina limbipennis J.-Duval simplex Chev.

9. Clivina insularis (J.-Duv.)

10. Clivina bipustulata (Fab.)

bipustula (Chev.)

11. Clivina biguttata Putz.

bisignata Chev. etc., not bisignata Putz.

12. Dyschirius sublævis Putz.

13. Dyschirius erythrocerus Lec.

14. Oxydrepanus rufus (Putz.) brevicarinatus (Putz.)

\section{Ardistomus nitidipennis $n$. sp.}

Of average form for Ardistomus; black, not bronzed, very shining; appendages and a pair of large, rounded, scarcely oblique subapical spots rufous. Head with clypeus almost evenly truncate; vertex not impressed. Prothorax almost orbicular; lateral margins reaching base; disk with usual impressions. Elytra very shining, not at all alutaceous; striæ moderately impressed, impunctate, entire, second reaching nearly to base; third interval five-punctate on outer edge (constant in all specimens). Last ventral with two punctures each side near apex. Front tibia bidentate externally above apical digit; front tarsi rather widely dilated. Length $51 / 2-61 / 2 \mathrm{~mm}$.

Holotype (Museum of Comparative Zoölogy no. 19491) and 12 paratypes from Soledad (near Cienfuegos) Cuba, June, Oct. 21, Nov. $7 \& 9$; some taken in debris after heavy floods, others secured by treading down vegetation on the edge of a tiny brook in woods. 
This is the first red spotted Ardistomus known from the West Indies. It belongs in group 1, section 1 of Putzeys' revision (Ann. Soc. Ent. Belgique 10, 1866, 200-). It is close to A. convexa Putz., of which we have a broken specimen from Mexico, but differs in being slightly less convex and in having the elytra shining, not alutaceous as in convexa. The Cuban species is also brighter, with larger elytral spots. From A. obliquata Putz. of the eastern United States, including Florida, the Cuban species differs in being smaller, with different outline of prothorax, and with fewer setigerous punctures on the third elytral interval.

16. Ardistomus elongatulus Putz.

17. Ardistomus cyaneolimbatus Chev. gundlachi Putz. MS., Gundlach, etc.

18. Aspidogiossa vulnerata Putz. comma Putz.

\section{Schizogenius arimao n. sp.}

Subparallel, slightly depressed; rufous (immature) or black, appendages and lower surface always more or less rufescent. Head with mentum toothed; vertex seven-sulcate, central carinæ nearly parallel, only slightly converging anteriorly. Prothorax by measurement slightly wider than long; disk impunctate, slightly wrinkled transversely, with a single longitudinal sulcus each side of the median sulcus. Elytra rather deeply striate, striæ punctate basally, not apically; third and fifth intervals each with about seven, seventh with about four setigerous punctures (exact number slightly variable). Front tibia as usual in genus. Male with three setigerous punctures placed triangularly each side of last ventral; female with two setæ each side, near margin. Length $33 / 4-41 / 2 \mathrm{~mm}$.

Holotype $\hat{o}$ (Museum of Comparative Zoölogy no. 19492) anà 24 paratypes from Soledad (near Cienfuegos) Cuba, June, Oct. 19, Dec. $1 \& 3$; all washed from low gravel banks of the Arimao River. One paratype from Cumanayagua, Santa Clara, Cuba, June 10, F. de Zayas (in Coll. Estación E. Agronómica, Cuba). 
This is the first known West Indian Schizogenius. It is close to S. tristriatus Putz. of Mexico and Central America (several specimens examined) but is smaller and more convex than typical tristriatus (described as $5 \mathrm{~mm}$. long) and much smaller than variety longipennis Putz. (described as larger than tristriatus). Bates, in "Biologia," gives the size of his specimens of tristriatus as from $1 \frac{1}{2}$ to $23 / 4$ lines, which would include specimens as small as the Cuban ones. However, the identity of the various Central American forms referred to tristriatus seems to me very questionable, and since the Cuban form, if it really is tristriatus at all, is fairly constant and smaller than either of the described continental forms, it seems best to treat it as a distinct species at least temporarily. It can hardly prove to be less than a good subspecies. In Leconte's table of North American Schizogenius (Bull. Brooklyn Ent. Soc. 2, 1879, p. 34) arimao runs to lineolatus or sallei, but is smaller and more convex than either.

\section{Key to West Indian Bembidini}

The following key will help to define the numerous new species of Bembidiini which are described in the following pages. It includes all previously known West Indian species except Tachys picturatus Putz. (possibly a member of the vittiger group) and T. piceolus Laf. (possibly near corruscus), which I have not been able to identify in the material I have seen. It also excludes the completely blind Petrocharis eggersi Ehlers of St. Thomas, which I do not know.

1. Outer apical angle of front tibia normal, rounded; size $22 / 3-6 \mathrm{~mm}$. (Bembidion) ........2 Outer apical angle of front tibia obliquely truncate or truncato-emarginate; size $3 \mathrm{~mm}$. or (usually) less .......6

2. Dorsal elytral punctures practically on third stria; color plain dark rufous; length $4 \mathrm{~mm}$.

Bembidion jamaicense n. sp. Dorsal elytral punctures near middle of third interval; elytra more or less variegated 
3. Front of head not at all alutaceous; $22 / 3-31 / 3 \mathrm{~mm}$.

Bembidion darlingtoni Mutchler.

Front of head alutaceous; size larger. 4

4. Elytral striæ apically deleted or only lightly impressed. Bembidion viridicolle (Laf.).

Elytral striæ entire, about same depth throughout.......5

5. Prothorax with sides broadly but slightly sinuate before basal angles; latter only slightly prominent.

Bembidion fastidiosum (Laf.).

Prothorax with sides strongly and conspicuously sinuate before basal angles; latter rather prominent

Bembidion sparsum Bates.

6. Two setæ over each eye, but anterior sometimes shorter than posterior.....

One seta over each eye; head sunk in thorax nearly to eyes

(Micratopus) 27

7. Eyes moderate or large; antennæ sometimes moniliform, usually not.

Eyes much reduced, small or minute; antennæ moniliform (Limnastis) .......28

8. Antennæ moniliform, middle joints as wide as long .....9 Antennæ more slender.

9. Side margins of thorax broad, channeled, translucent; color castaneous with base and apex of elytra pale; size under $2 \mathrm{~mm}$.

Tachys (Tachyta) flavicauda autumnalis Bates. Side margins of prothorax narrower, not translucent; color dark piceous, elytra each with a subapical red spot; size $\pm 2 \frac{1}{2} \mathrm{~mm}$.

Tachys (Tachyta) hispaniolae n. sp.

10. Elytra each with six coarsely punctate striæ beside the marginal series of punctures; size $\pm 2-21 / 2 \mathrm{~mm}$.

Pericompsus blandulus Schaum.

Elytra with not more than five coarsely punctate striæ beside marginal series, or striæ not coarsely punctate .11 
11. Posterior dorsal puncture of elytron (on outer edge of third interval, as a rule) much in front of apical recurved stria; body very convex.

Posterior dorsal puncture of elytron on or within hooked tip of apical recurved stria; body usually more depressed

12. Elytra each with five coarsely punctate striæ or rows of punctures; mentum bi-perforate

Tachys (subgenus?) immaculatus (Bates).

Elytra each with only one or two striæ, which are impunctate; mentum not perforated

Tachys (Tachyura) xanthopus Dej.

13. Posterior elytral puncture directly upon hooked tip of apical recurved stria; surface not iridescent...............14 Posterior elytral puncture within, not on, hooked tip of apical recurved stria; surface usually more or less iridescent

14. Basal angles of prothorax obtuse

Tachys bradycellinus Hayw. Basal angles of prothorax right. Tachys occultator Casey (and) Tachys ensenadae Mutchler.

15. Male with two joints of front tarsus dilated ..............16 Male with only basal joint of front tarsus dilated ......20

16. Antennæ very slender (middle joints about three times as long as wide; tip of sixth reaching about to basal angle of prothorax); eyes moderate; length $\pm 3 \mathrm{~mm}$.

Tachys albipes Lec. Antennæ stouter and shorter; other characters variable

17. Eyes abruptly prominent, forming right angles with sides of head behind them; basal angles of prothorax obtuse but distinct; length just over $21 / 2 \mathrm{~mm}$.

Tachys abruptus n. sp.

Eyes less prominent, forming obtuse angles with sides of head behind them; other characters variable 18 
18. Basal angles of prothorax very obtuse, almost rounded except for minute subprominent sinuation of margin; size $\pm 21 / 2 \mathrm{~mm}$.

Tachys putzeysi F. \& S. Basal angles of prothorax obtuse but rather distinct; size $2-21 / 4, \mathrm{~mm}$.

19. Prothorax transverse, head relatively narrow (Pl. 1, fig. 1) Tachys dominicanus $\mathrm{n}$. sp. Prothorax less transverse, head broader

Tachys sp. (Guadeloupe \& Montserrat.)

20. Surface of elytra with very fine, short, sparse pubescence Tachys striax n. sp. Surface of elytra not pubescent.

21. Posterior angles of prothorax accurately and minutely formed; color testaceous with head scarcely darker ...22 Posterior angles of prothorax finely blunted or bluntly subdenticulate; color castaneous, or partly testaceous with head much darker.............................................25

22. Form unusually slender, parallel..............................23

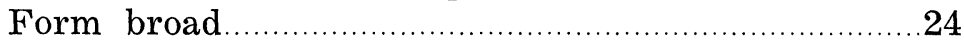

23. Base of prothorax oblique at sides; eyes very prominent. Tachys filax $\mathrm{n} . \mathrm{sp}$. Prothorax squarely truncate at base; eyes less prominent Tachys pumilus Dej.

24. Median line of prothorax continued as a groove behind posterior transverse impression; first joint male front tarsus very wide; size $\pm 21 / 2 \mathrm{~mm}$.

Tachys cubax n. sp. Median line of prothorax not continued behind posterior transverse impression; first joint male front tarsus relatively much narrower; size just under $2 \mathrm{~mm}$.

Tachys paulax n. sp.

25. Sides of prothorax sinuate before basal angles, which would be almost right except are slightly blunted; head and prothorax relatively narrow; size $\pm 21 / 2 \mathrm{~mm}$. 
Sides of prothorax scarcely or not sinuate before the basal angles, which are more obtuse; other characters variable 26

26. Color usually castaneous or darker; head and prothorax relatively narrower; antennæ more slender (middle joints more than twice as long as wide) ; first joint male front tarsus wider and with outer apical angle more strongly produced; size $\pm 21 / 2 \mathrm{~mm}$.

Tachys corruscus Lec. Color testaceous with head much darker; head and prothorax relatively wider; antennæ stouter (middle joints less than twice as long as wide) ; first joint male tarsus smaller; size $2 \mathrm{~mm}$. or slightly less

Tachys vorax Lec.

27. Head moderate; prothorax not especially large; size about $12 / 3 \mathrm{~mm}$. Micratopus insularis $\mathrm{n}$. sp. Head very small; prothorax relatively very large; size $\pm 2 \mathrm{~mm}$. (Pl. 5, fig. 3) ........ Micratopus parviceps n. sp.

28. Form slender; head relatively small; length $11 / 2-12 / 3 \mathrm{~mm}$. (Pl. 5, fig. 2.) Limnastis americanus n. sp. Form less slender; head relatively large; length barely over $1 \mathrm{~mm}$. Limnastis capito Bates.

\section{Bembidion (Peryphus) jamaicense n. sp.}

Moderately slender, convex, upper surface faintly alutaceous but rather shining; dark rufous, appendages testaceous. Head rather long; eyes prominent; antennæ slender; front with inconspicuous median puncture; frontal sulci moderate, parallel; mentum with rounded-triangular tooth at middle. Prothorax subcordate, about one-third wider than long (by measurement); basal angles acute but not much more than right, strongly carinate; disk with transverse impressions moderate, longitudinal line strong. Elytra with first and second striæ entire, third nearly entire, fourth to sixth obliterated near apex except fifth apically sulciform, seventh indicated by a few faint punctures in basal half, eighth near margin; striæ moderately punctate basally, 
smooth apically; intervals slightly convex, third with two distinct setigerous punctures practically on third stria. Length just over $4 \mathrm{~mm}$.

Holotype $\hat{o}$ (United States National Museum) and $1 \%$ paratype (Museum of Comparative Zoölogy no. 19498) from Jamaica, H. G. Hubbard.

This species is superficially similar to Bembidion subangustatum Hayw. (type examined) of New Mexico and Arizona, but, in addition to being considerably smaller, has a rather differently shaped prothorax and a larger head with more prominent eyes. Of the known Central American Bembidion it is related only to rogersi Bates, of which we have specimens, identified by description, from Cerro Central, Costa Rica. The Jamaican species is less convex, much paler, lacks æneous lustre, has the dorsal punctures of the elytra less impressed and nearer the third stria, has more slender antennæ, and differs slightly in other ways.

20. Bembidion (Notaphus) sparsum Bates.

21. Bembidion (Notaphus) viridicolle Laf. chevrolati (G. \& H.) apicale J.-Duv.

\section{Bembidion (Notaphus) fastidiosum Laf.}

I have seen specimens from Haiti and Puerto Rico but none from Cuba, although the species is recorded as Cuban by Leng and Mutchler.

\section{Bembidion (Notaphus) darlingtoni Mutchler.}

affine auct., not Say.

Described in the American Museum (New York) Novitates no. 686,1934, p. 3.

\section{Tachys (Tachyta) flavicauda autumnalis Bates.}

Tachys (Tachyta) hispaniolae $n$. sp.

Of average form for Tachyta; rufo-piceous to piceous black, rufescent below, appendages and a nearly round red spot at apical third of each elytron near middle of its width testaceous; upper surface entirely alutaceous. 
Head: front with two slightly impressed, widely separated sulci slightly converging anteriorly; antennæ short, second joint shorter than third, middle joints hardly longer than wide; mentum without foraminiform punctures, with blunt tooth in emargination. Prothorax slightly more than a half wider than long (by measurement) ; sides rounded anteriorly, slightly and very gradually sinuate posteriorly; posterior angles acutely but very minutely denticulate, costæ within angles short and not conspicuous; lateral margins evenly explanate, wider than in Tachys (Tachyta) inornata (Say), less wide than in T. flavicauda; basal transverse impression deep, anterior faint, median line rather deep. Elytra only slightly depressed; sutural stria deep and entire, recurved as usual; other striæ all more or less abbreviated but all visible basally, either as impressed faintly punctate lines or (externally) as series of small punctures; fourth stria with fixed punctures near base and about apical third. Two basal joints of male front tarsus dilated and with anterior apical angles slightly produced. Length $\pm 21 / 2 \mathrm{~mm}$.

Haiti, W. M. Mann: Holotype (Museum of Comparative Zoölogy no. 19499) and 3 paratypes from Grande Rivière; 2 paratypes from St. Marc.

This species is apparently not closely related to any of those known from North or Central America; its color pattern is unique. It is intermediate between the so-called genera Tachyta and Tachymenis as used by Casey (Memoirs 8,1918, p. 3).

25. Tachys (Pericompsus) blandulus Schaum

26. Tachys (Tachyura) xanthopus (Dej.)

27. Tachys (subgenus?) immaculatus (Bates)

28. Tachys (s. s.) occultator Csy.

29. Tachys (s. s.) bradycellinus Hayw.

30. Tachys (s. s.) cubax n. sp.

Rather broad; not strongly depressed; rufo-testaceous with a small, vague, dark blotch common to both elytra 
behind middle; very faintly opalescent. Head with eyes only moderately prominent; antennæ with middle joints about twice as long as wide; frontal sulci parallel, deep anteriorly, abbreviated and obsolete posteriorly; mentum toothed at middle, conspicuously bi-foraminate posteriorly. Prothorax just over a half wider than long (by measurement), squarely truncate at base and apex; disk with usual impressed lines, and with median longitudinal line continued posteriorly as a conspicuous groove behind the basal impression; base broad, angles obtuse but almost right, very precisely defined, not in the least blunted or rounded. Elytra each with seven striæ in addition to the marginal one, but the seventh almost obsolete; two inner striæ entire, others abbreviated apically; several inner striæ slightly impressed, outer ones very superficial; striæ slightly irregular but not distinctly punctate; anterior dorsal puncture close to fourth stria about a third or a fourth from base, posterior puncture within tip of recurved stria. Male with only first joint of anterior tarsus dilated, with anterior apical angle much prolonged and acute. Length $\pm 21 / 2 \mathrm{~mm}$.

Holotype of (Museum of Comparative Zoölogy no. 19500) and 1 i paratype from Soledad (near Cienfuegos) Cuba, Oct. 28, taken under cover beside a little brook in a saboruco or patch of rough, scrubby woods; 1 o paratype from San Carlos Est., Guantánamo, Cuba, Oct. 4-8 (American Museum) ; 1 of specimen, not a type, from Bath, Jamaica, Apr. 3-6 (American Museum) ; 1 \& paratype from Cayamas, Sta. Clara, Cuba, Feb. 15, E. A. Schwartz (United States National Museum) ; 1 ô paratype from Jatibonico, Cuba, Oct. 30, in soil of sugar cane field, L. D. Christenson (U. S. N. M.).

The form of the first tarsal joint of the male distinguishes this species from all our North American Tachys $s$. $s$. except corruscus Lec. As compared with the latter cubax is differently colored, broader, less depressed, the frontal sulci are conspicuously shorter, the antennæ stouter, the prothorax broader at base with more precisely formed basal angles and with an extreme basal median channel. The two species are not really very closely related. Cubax is 
probably closer to Tachys platyderus Bates, and its allies, of the Amazonian region, but the type of elytral striation combined with the barely sinuate sides of the prothorax apparently distinguish it from all of them.

In coining the name cubax I am following the example of Leconte, who made a habit of using two-syllable names ending in $a x$ for species of this genus.

\section{Tachys (s. s.) paulax n. sp.}

Rather broad, not strongly depressed; rufo-testaceous with slight opalescent lustre. Characters in general the same as in the preceding species except that the sides of the prothorax are slightly more sinuate before the base, the median line of the prothorax is not continued behind the posterior transverse impression, the first joint of the male front tarsus is much less dilated, and the size is smaller. Length just under $2 \mathrm{~mm}$.

Holotype of (United States National Museum) and $1 \%$ paratype (Museum of Comparative Zoölogy no. 19501) from Cayamas, Sta-Clara, Cuba, March 2, E. A. Schwarz.

\section{Tachys (s. s.) albipes Lec.}

Tachys (s. s.) abruptus n. sp.

Broad, somewhat depressed ; rather shining rufo-castaneous with slight iridescence, appendages paler. Head with abruptly prominent eyes which form right angles with the sides of the head behind them (when seen from a line perpendicular to the front) ; antennæ with middle joints less than twice as long as wide. Prothorax by measurement just over one and a half times as wide as long; sides barely sinuate before basal angles, which are obtuse but distinct; disk with usual impressed lines. Elytra broadly oval, each with about three inner striæ more or less distinct and one or two outer ones faintly indicated; striæ not distinctly punctulate; anterior dorsal puncture about on fourth stria a third from base, posterior puncture within recurved tip of apical striole. Male with two basal joints of each front tarsus rather widely dilated. Length just over $21 / 2 \mathrm{~mm}$. 
Holotype $\hat{o}$ (American Museum) and 4 paratypes

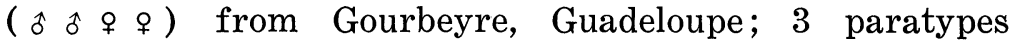
( $x$ ㅇ $q$ ) from Long Ditton, Dominica, July 21, 1911. Paratypes in the Museum of Comparative Zoölogy (no. 19496) and the American Museum.

This species is distinguishable from its relatives (the preceding and the three following species) by its more abruptly prominent eyes, as well as by other characters given in the key.

\section{Tachys (s. s.) putzeysi F. \& S.}

Gourbeyre, Guadeloupe, 7 specimens (American Museum). One specimen has been compared with the type in the Paris Museum by Dr. Jeannel, to whom I sent for comparison specimens of all five Lesser Antillean Tachys known to me.

Tachys (s. s.) dominicanus n. sp. (Pl. 5, fig. 1)

Rather broad and depressed; shining rufo-testaceous, iridescence very faint, appendages paler. Head relatively small, with poorly developed eyes; antennæ with middle joints rather less than twice as long as wide. Prothorax by measurement just over one and a half times as wide as long, sides oblique or just sinuate before the obtuse but distinct basal angles; disk with usual impressed lines. Elytra each with about two inner striæ distinct and several outer ones indicated; striæ irregular, almost punctulate; anterior dorsal puncture about on fourth stria a third from base, posterior puncture within recurved tip of apical striole. Male with two basal joints of each front tarsus moderately dilated. Length $2-21 / 4 . \mathrm{mm}$.

Holotype of (American Museum) and 16 paratypes from Long Ditton, Dominica, June 21, 1911. Paratypes in the Museum of Comparative Zoölogy (no. 19497) and American Museum.

The distinguishing characters of this species are sufficiently given in the key.

33. Tachys (s. s.) scitulus Lec. 


\section{Tachys (s. s.) corruscus Lec. (not typical)}

35. Tachys (s. s.) vorax Lec.

36. Tachys (s. s.) striax n. sp.

Moderately stout, depressed; rufo-testaceous (elytra rarely piceous with base paler), iridescent lustre faint or absent; head only slightly darker. Head with eyes only slightly prominent; antennæ with middle joints about twice as long as wide; frontal grooves moderate, slightly converging anteriorly; front faintly micro-reticulate, with distinct small puncture at middle; mentum toothed at middle, with two large foraminiform perforations. Prothorax cordate, about a half wider than long (by measurement), sides strongly sinuate before the prominent and acute (but not much more than right) basal angles; usual discal impressions well marked. Elytra finely, sparsely, inconspicuously pubescent, (pubescence visible only under high magnification) ; with about five striæ including the sutural visible on each, the inner two or three somewhat impressed, irregularly and inconspicuously punctulate, or at least with sides of intervals irregular; sutural stria reaching base of elytron, it and second stria reaching apex (second sulciform apically), others abbreviated; anterior setigerous puncture almost on fourth stria about a third from base, posterior puncture within tip of hooked apical striole. Male with first joint of front tarsus moderately dilated, with anterior apical angle acutely but not strongly produced. Length $2 \mathrm{~mm}$. or slightly less.

Holotype ô (Museum of Comparative Zoölogy no. 19502) and 19 paratypes from Soledad (near Cienfuegos) Cuba, June, Oct. $17 \& 20$, Nov. 7. One specimen was taken under a stone in a dry field; practically all the others, in a plowed field during a heavy flood. 1 paratype from Cayamas, Sta. Clara, Cuba, June 6, E. A. Schwarz (United States National Museum) ; 1 paratype from Cuba, Poey Collection no. 27 (Philadelphia Academy of Sciences).

This species is strongly characterized by the pubescent and striate elytra with the second stria sulciform apically. So far as I know, it has no close relatives. 


\section{Tachys (s. s.) pumilus (Dej.)}

38. Tachys (s. s.) filax n. sp.

Slender, subdepressed; testaceous, rather shining. Head nearly as wide as prothorax; eyes very prominent; antennæ rather stout, middle joints about a half longer than wide, apex of eighth joint reaching about to base of prothorax; mentum with two foraminiform punctures. Prothorax cordate, slightly less than a half wider than long (by measurement) ; base oblique at sides; sides sinuate before the obtuse (but nearly right) posterior angles, which are accurately defined. Elytra each with two inner striæ slightly impressed and one or two others more or less indicated; striæ slightly irregular but not distinctly punctate; apical recurved stria well marked and long, but second stria scarcely visible at apex; anterior dorsal puncture on third interval near basal third, posterior puncture within tip of recurved stria. Length $\pm 17 / 8 \mathrm{~mm}$.

Holotype $\&$ (United States National Museum) and 1 \& paratype (Museum of Comparative Zoölogy no. 19503) from Cayamas, Sta. Clara, Cuba, E. A. Schwarz, Jan. 30 and Feb. 13. Also 1 ( 8 ?) paratype from Cuba, Poey Collection no. 27 (associated with Poey specimen of preceding species) (Philadelphia Academy of Sciences).

This is a very graceful species which approaches the form of the vittiger group of Tachys, but has the characters of Hayward's proximus group. It is distinguished from Tachys pumilus (Dej.), apparently its nearest ally, by much more prominent eyes, base of prothorax oblique at sides, and more slender form.

39. Limnastis americanus n. sp. (Pl. 5, fig. 2.)

Small, slender, subdepressed; rufo-testaceous, head not darker. Head with front micro-reticulate; eyes small to very small (see below), flattened, sometimes slightly convex, sometimes actually concave; two supraorbital setæ each side, anterior one shorter; antennæ short, stout, outer joints moniliform; mentum without tooth in emargination. Prothorax by measurement about a third wider than long, 
somewhat narrowed behind, sides broadly, not strongly sinuate before base; posterior angles obtuse or finely right; anterior angles without very conspicuous setæ; disk microreticulate, not obviously punctate, with fine, short sparse pubescence. Elytra reaching tip of abdomen, subtruncate, slightly dehiscent near apex; about three inner striæ faintly impressed on each elytron; intervals each with a single row of fine, short pubescence; one inconspicuous discal puncture on the outer edge of the third interval, almost on the third stria, a little behind the middle. Inner wings dimorphic, well developed or reduced to about a third elytral length. Male front tarsi each with two basal joints dilated. Length $11 / 2-12 / 3 \mathrm{~mm}$.

Holotype macropterous $\hat{o}$ (Museum of Comparative Zoölogy no. 19504) and 16 paratypes (3 macropterous ô $\hat{o}$, 7 macropterous $q$ \&, 3 micropterous ôे $\hat{o}$, and 3 specimens with wings not examined) all from Soledad (near Cienfuegos) Cuba, June, Oct. 27, Dec. 1; most of them taken by treading down dense vegetation floating in deep water. They may possibly have been carried there by floods, but were not in real flood debris. Also 4 paratypes (all macropterous q \&) from Cayamas, Sta. Clara, Cuba, Jan. 2 \& 29, Feb. $7 \& 13$, E. A. Schwarz (United States National Museum).

The dimorphism of the inner wings is correlated with the size of the eyes. The macropterous specimens have the eyes larger, usually slightly transverse, separated below from the margin of the mouth by about half or less the diameter of the eye itself. The three micropterous males have the eyes smaller, almost evenly rounded, and separated from the mouth by about their own diameter.

This species is emphatically a Limnastis, not a Micratopus, as shown by comparison with several American species of the latter genus and with a specimen of Limnastis macrops Jeannel kindly sent me by Dr. Jeannel himself. In the latter's table of the genus (Livre Cent., Soc. Ent. France, 1932 , pp. 174 -) the macropterous form of the Cuban species runs to near $L$. coomani Jeannel of Tonkin, but has smaller eyes and differs in other ways. This does not, of course, indicate an actual affinity between the Chinese and 
Cuban species, for somewhat similar species of Limnastis occur over a large part of the Old World, including the Mediterranean region. There is even one, L. gaudini Jeannel, in the Canary Islands, but it is completely blind. Only one true Limnastis has been known before from the New World, L. capito Bates. This was described from Guatemala but occurs also in Cuba. Mr. K. G. Blair has very kindly compared a Cuban specimen for me with the type in the British Museum. The distinguishing characters of the two American species are given in the key, in the preceding pages.

40. Limnastis capito Bates.

41. Micratopus parviceps n. sp. (Pl. 5, fig. 3.)

Form and proportions as figured; body depressed; surface microreticulate but moderately shining; testaceous, head only faintly darker. Head very small, with small, flat eyes which scarcely break the outline of the sides of the head; middle joints of antennæ about twice as long as wide. Prothorax very large, broadly emarginate in front, sides of base oblique; basal angles very: obtuse; disk depressed, median line distinct, basal transverse impression faint, anterior impression absent. Elytra depressed, independently rounded-subtruncate at apex; striation nearly complete, but striæ very fine, shallow, and inconspicuous; one dorsal puncture near apex of third stria. Length $\pm 2 \mathrm{~mm}$.

Holotype (United States National Museum) and 5 paratypes from Jatibonico, Cuba, Apr. 9, Apr. 20, and July 8, L. D. Christenson, in soil of sugar cane fields. Paratypes in Museum of Comparative Zoölogy (no. 19505) and United States National Museum.

This species differs from Micratopus ænescens (Lec.) and fusciceps Csy. of the United States in having the elytral striæ very fine and inconspicuous; from withycombei Jeannel of Trinidad (Livre du Cent., Soc. Ent. France, 1932, 168) in having the basal angles of the prothorax much more obtuse. The new species is apparently unique in the small size of the head. 
Micratopus insularis n. $\mathrm{sp}$.

So similar to the preceding as not to require a full description. Differs (from parviceps) in being smaller, slightly more convex, with relatively smaller prothorax and larger head with larger, more prominent eyes. Length $\pm 12 / 3 \mathrm{~mm}$.

Holotype (United States National Museum) and 1 paratype (Museum of Comparative Zoölogy no. 19506) from San Juan, Puerto Rico, Aug. 11, 1933, A. S. Mills, at light.

\section{Diplochaetus rutilus (Chev.).}

\section{Perileptus (s.s.) columbus n. sp. (Pl. 5, fig. 4.)}

Form and proportions as figured; depressed; entirely rufo-testaceous; upper surface with fine, short pubescence which does not conceal the underlying surface. Head across eyes by measurement barely narrower than prothorax, but appearing slightly wider; temples parallel for a short distance behind eyes before being constricted; front shining, obsoletely punctate; antennæ slender, median joints about three times as long as wide; mentum toothed, tooth subtruncate apically. Prothorax cordate; base more than two-thirds (by measurement) as wide as widest part; sides sinuate about one-sixth from base, thence nearly straight to the regular, right or slightly obtuse basal angles; lateral margin moderate, entire, crenate near base; disk rather finely and closely punctate, basal transverse line very deep, anterior line less deep, median longitudinal line well impressed. Elytra also rather closely and finely punctate; sutural stria distinct except at base, one or two next striæ vaguely indicated; three discal punctures on position of third stria on each elytron, about a fifth from base, just behind middle, and about a tenth from apex respectively. Male with first two joints of front tarsus somewhat dilated. Length $21 / 4-23 / 4, \mathrm{~mm}$.

Holotype of (Museum of Comparative Zoölogy no. 19507) and 9 paratypes ( 2 in collection Jeannel), including both sexes, from Soledad (near Cienfuegos) Cuba, Oct. $27 \& 28$, 
Nov. 24, Dec. 1, taken in gravel bars beside woodland brooks.

For comparative remarks see under the following species.

Perileptus (s. s.) jeanneli n. sp.

Form closely similar to that of the preceding species; depressed; piceous; mouth, bases of antennæ, palpi, legs, and feet rufescent to testaceous. Head: antennæ very slender, median joints about four times as long as wide; head otherwise about as in columbus. Prothorax cordate, strongly constricted at base, which is very slightly less than two thirds as wide as widest part; basal angles right. Elytra with sutural stria very lightly impressed, obsolete at base; other striæ barely or not at all suggested by irregularities of the elytral surface; three dorsal punctures on position of (obsolete) third stria. Length $3 \mathrm{~mm}$. or slightly less. Male not known.

Holotype $q$ (Museum of Comparative Zoölogy no. 19508) and 6 paratypes ( 2 in collection Jeannel) from Kingston, Jamaica, Feb. 14, 1928; taken in gravel bars of a large stream in the outskirts of the city during half a day of collecting, all that I have ever done on the island.

This species is close to the preceding, but is perfectly distinct by the much darker color, more slender antennæ, relatively narrower prothoracic base, and slightly larger size. Both species belong to the areolatus group of Perileptus. Dr. Jeannel, who has very kindly examined specimens sent to him and confirmed my identification of them as Perileptus, writes that the two West Indian species differ from previously known species of the areolatus group only in being more depressed, more closely punctate, and with the elytral striæ more effaced. They are especially closely related to $P$. nigritulus Woll. of Madeira.

No species of Perileptus, and indeed none of the Perileptini, has been known before from the New World. The West Indian species are especially interesting in that the well characterized areolatus group to which they belong is known otherwise (according to Dr. Jeannel's fine mono- 
graph in l'Abeille, Vol. 32, 1926, pp. 402 -) only in Europe, North Africa, and the Atlantic Islands.

\section{Panagaeus quadrisignatus Chev. thomae Schaum.}

45. Coptia sauricollis n. sp. (Pl. 5, fig. 5.)

Piceous black, shining, with rather inconspicuous pale pubescence; antennæ (except the three basal joints, which are dark), palpi, and tarsi testaceous; tibiæ and parts of femora more or less reddish. Head nearly smooth except irregularly bi-impressed between eyes; clypeus impressed each side, impressions joined by a fine, arcuate line; mentum shallowly emarginate, with a pronounced rounded tooth in emargination; antennæ slender, apex of eighth joint reaching about to base of pronotum, third joint slightly longer than following ones. Prothorax very broad, much narrowed anteriorly, emarginate in front, bi-spinose each side at base; lateral margins very deeply channeled anteriorly, gradually obliterated posteriorly near first spine; disk coarsely punctate, finely pubescent, surface between punctures shining. Elytra deeply crenato-striate; intervals convex, shining, but with minute punctures bearing fine pubescence. Lower surface shining, only partly pubescent; epipleuræ below humeri impunctate and almost without pubescence; sides of pro-, meso-, and metathorax almost without pubescence, coarsely punctate; ventral segments with only comparatively fine punctuation except sides of basal segments with a few coarse punctures. Male tarsi not dilated. Length 53/4-7; width $3-33 / 4, \mathrm{~mm}$.

Holotype $\&$ (Museum of Comparative Zoölogy no. 19509) and 6 paratypes, including both sexes determined by dissection, from Soledad (near Cienfuegos) Cuba, June, Nov. $7 \& 21$; all collected by myself in flood debris.

Coptia, previously known only from two species occurring in Cayenne, Venezuela, and Brazil, differs from Panagæus essentially only in having the front tarsi similar in the two sexes; secondary differences are that the antennæ are more slender in Coptia, with proportionately shorter third joint, 
and that the body is less obviously pubescent, more shining, and not spotted. We possess a single specimen of $C$. armata (Cast.) from St. Augustine, Trinidad. This species is figured by Kollar (Ann. Wiener Mus. 1, 1836, t. 31, figs 3a, b) and both previously known species have been accurately described and compared by Chaudoir (Ann. Soc. Ent. Belgique 21, 1878, 167-9). The present species differs from them, $i$. e. from Coptia armata (Cast.) and C. marginicollis Chd., in having a differently shaped prothorax, less narrowed anteriorly, with the basal spines better developed.

46. Coptia effeminata n. sp. (Pl. 5, fig. 6.)

Black, rather shining, with inconspicuous pale pubescence; antennæ (except three darker basal joints), palpi, and tarsi brownish. Head nearly smooth except bi-impressed between eyes; clypeus impressed each side, transverse arcuate line faint; mentum shallowly emarginate, with a broad short tooth in emargination; tooth truncate, even slightly emarginate apically; antennæ with apex of eighth joint reaching about to base of prothorax, third joint slightly longer than following one. Prothorax broad, narrowed anteriorly, emarginate in front, unidentate (not bispinose) each side of base; lateral margin gradually obliterated anteriorly, not deeply channeled; disk somewhat depressed near posterior angles, coarsely punctate, moderately pubescent. Elytra above about as in preceding species. Lower surface shining, mostly inconspicuously pubescent; epipleuræ below humeri with two widely separated rows of coarse punctures; all ventral segments with very coarse punctuation across their entire width. Length $\pm 81 / 2$; width $\pm 4 \mathrm{~mm}$.

Holotype $\&$ (Museum of Comparative Zoölogy no. 19510) from Soledad (near Cienfuegos) Cuba, Nov. 9, taken at light at "Harvard House." Paratypes: 1 i (sex determined by dissection) from Central Jaronú, Cuba, July 10, at light, L. C. Scaramuzza (United States National Museum) ; 1 (sex not determined) from Baraguá, Cuba, Nov. 12, at light, C. F. Stahl (U. S. N. M.) ; 1 ( $\operatorname{sex}$ not de- 
termined) from Camagüey, Cuba, Aug.-Sept., J. M. Osorio (Collection Estación E. Agronómica, Cuba).

This species differs radically from Coptia sauricollis in the much reduced armature of prothorax, absence of deep channeling in prothoracic margin anteriorly, and punctuation of epipleuræ and abdomen. The species represents in these ways an approach to Panagæus, but is nevertheless referable to Coptia, as shown by the narrow male tarsi, sparse pubescence, etc.

\section{Morion georgiae (Beauv.). monilicornis (Latr.).}

Morion costigerus $n$. sp.

Parallel, subdepressed, entirely black, somewhat shining. Head : clypeus obtusely quadridentate; front with two longitudinal, somewhat sinuous sulci anteriorly; eyes less abruptly prominent than in georgix. Prothorax formed nearly as in georgize but more elongate, only about a tenth (by measurement) wider than long. Elytra with moderately impressed striæ, latter impunctate; intervals only slightly convex except that seventh is strikingly costiform in about basal third; sixth interval sloping inward basally so that fifth stria is at bottom of an obtuse V-shaped depression; third interval with single puncture near second stria just before apical third. Last ventral with one setigerous puncture about a third from apex on each side. Hind trochanters practically half as long as femora, rounded apically. Length $17-20 \mathrm{~mm}$.

Jamaica: holotype (Museum of Comparative Zoölogy no. 19511) from Newton, 3,000 ft., Jan., C. T. Brues; 1 paratype (M. C. Z.) from Cinchona, 5,000 ft., Jan., Brues; 2 paratypes (American Museum) from Cumberland District, Clarendon, Dec. 15-18, about 3,000 ft.

This species may be known at once from all previously described American Morion by the very conspicuously costate seventh elytral intervals, which are much more elevated than in $M$. simplex Dej. Otherwise it somewhat resembles a very large, slender $M$. georgix, with which it agrees absolutely in all characters of generic value. 
48. Pterostichus (Poecilus) chalcites (Say).

49. Loxandrus nocticolor $\mathrm{n}$. $\mathrm{sp}$.

Of average form for Loxandrus; shining black, without evident iridescence; tarsi, palpi, and basal joints of antennæ partly or irregularly rufous. Head normal for genus; clypeus and front anteriorly longitudinally impressed each side; mentum tooth moderate, rounded truncate apically as usual. Prothorax a fourth or a third wider than long (by measurement) ; margin moderate, not wider or more explanate basally; sides almost evenly rounded from apex to base; base obliquely rounded each side to the very obtuse basal angles; disk rather flat; median line fine, abbreviated at both ends; basal foveæ deep, linear, about a third length of prothorax; base near foveæ finely, sparsely punctate. Elytra rather convex, deeply striate; striæ impunctate; intervals convex, third with puncture on inner edge before middle. Front tarsi of male with joints obliquely dilated. Length $101 / 2 \mathrm{~mm}$.

Holotype $\hat{o}$ (Museum of Comparative Zoölogy no. 19512) and $1 \&$ paratype from Soledad (near Cienfuegos) Cuba, Oct. 21, taken in flood debris.

Absence of iridescent lustre combined with unusual depth and perfect smoothness of the elytral striæ make this an unusually well characterized species.

50. Loxandrus celeris (Dej.). cubanus Tsch. cruentatus (Chev.) (Stenolophus).

For some time I have suspected the identity of Stenolophus cruentatus Chev. with this species, and recently Mr. K. G. Blair has compared a specimen sent to him with Chevrolat's type (at Oxford) and confirmed my suspicions.

51. Loxandrus crenatus Lec.

Colpodes M'Leay and Glyptolenus Bates

The following table of the known West Indian species of these genera will show the systematic position of the several 
new species described below, and at the same time will summarize the West Indian fauna. I have placed asterisks before the species I have not seen. The table is based on Chaudoir's monograph (Ann. Soc. Ent. France (5) 8, 1878, pp. 279 -). The only species I have not been able to place in the table is Metallosomus cuprascens Mots., which is omitted in Chaudoir's monograph. The species may be near mannerheimi. It was described from Santo Domingo.

1. Metepisterna only a little longer than wide; color dark

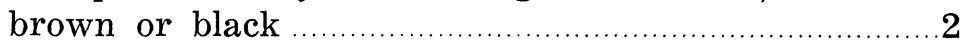

Metepisterna very elongate; color variable ...................4

2. Elytra narrowly and regularly ovate; humeri obliterated; Length $91 / 2 \mathrm{~mm}$.; Martinique and Dominica.

C. ellipticus Chd.

Elytra not evenly ovate; humeri distinct

3. Length $\pm 8-9 \mathrm{~mm}$; Jamaica C. cinchonæ n. sp.

Length $\pm 11 \mathrm{~mm}$.; Santo Domingo

${ }^{*}$ C. jægeri Dej.

Length 13-15 mm.; Jamaica

C. macer n. sp.

4. Tibiæ canaliculate above; prothorax subquadrate 5

Tibiæ not canaliculate above; prothorax variable 6

5. Color nearly uniform piceous brown; elytra strikingly short, broad, and convex; side margins of prothorax very narrow anteriorly; $71 / 2 \mathrm{~mm}$.; Dominica.

Glyptolenus simplicicollis n. sp. Black, elytra bluish, relatively narrow; side margins of prothorax normal; 7 mm.; Guadeloupe (and Brazil)

C. chalybeus Dej.

6. Fourth joint of posterior tarsus strongly lobed externally

Fourth joint of posterior tarsus not or scarcely more strongly lobed externally than internally; color never metallic

7. Dark piceous, elytra cœruleo-viridescent; $111 / 3 \mathrm{~mm}$; Santo Domingo... *C. mannerheimi Chd. (jägeri Mann.) Without metallic lustre; $12 \mathrm{~mm}$.; Jamaica

C. vagepunctatus $\mathrm{n} . \mathrm{sp}$. 
8. Odd intervals (except first) of elytra foveolate; $10 \mathrm{~mm}$.; Guadeloupe ........................ ${ }^{*} C$. alternans Chd. Odd intervals of elytra not foveolate

9. Striæ of elytra interrupted; $9 \mathrm{~mm}$.; Haiti

C. fractilinea n. sp.

Striæ of elytra not interrupted.

10. Head relatively narrow, less than half width of elytra at widest point.

Head more than half as wide as elytra at widest point 12

11. Brown, dull; striæ of elytra lightly impressed; sides of prothorax broadly, not strongly rounded; 8-11 mm.; Guadeloupe ................. C. dejeani Chd. (brunneus Dej.) Black, shining; elytral striæ more impressed; sides of prothorax more strongly rounded; $10.5 \mathrm{~mm}$.; Cuba

Colpodes sp.

12. Length 8-10 mm.; Guadeloupe C. lherminieri Chd. Length 10-13 mm.; Guadeloupe ${ }^{*}$ C. elongatus Chd. Length 13-17 mm.; Guadeloupe........ ${ }^{*}$ C. memnonius Dej.

\section{Colpodes cinchonae n. sp.}

Slender, elongate, rather depressed; piceous, appendages rufo-testaceous. Head relatively broad, with usual impressions anteriorly; front smooth; antennæ rather slender. Prothorax only about a fifth or less wider than head across eyes, about as long as wide (by measurement) ; lateral margin rather narrow for genus; posterior angles right but finely blunted; disk somewhat shining, with usual impressions. Elytra broadly sinuate near apex; apices slightly prolonged, each subangulate; striæ rather fine, impunctate; intervals nearly flat, dull and alutaceous, third tripunctate, the first puncture near the third stria about basal fifth, others near second stria about middle and apical third. Inner wings vestigial. Metepisterna short; tibiæ not canaliculate externally; tarsi lightly sulcate at sides above, the sulci widely separated, fourth joint bilobed but scarcely produced externally, fifth joint not ciliate; male tarsi slightly dilated. Length $\pm 8-9 \mathrm{~mm}$. 
Holotype $\&$ (Museum of Comparative Zoölogy no. 19513) from Cinchona Jamaica, 5,000 ft., Jan., C. T. Brues; 11 paratypes (American Museum and M. C. Z.) from the same locality, Feb. 26.

In Chaudoir's tabulation of Colpodes $(l . c$.$) this species$ would fall nearest to $C$. sphodroides Chd. and $C$. pristonychoides Chd. of Mexico, but it is much more slender than either, with a relatively larger head, as shown by comparison with our small series of sphodroides from "Biologia" material. It is very similar indeed to Colpodes lherminieri Chd., but the metepisterna are much shorter, the head relatively larger, and the elytra more opaque than in that species.

Colpodes macer n. sp. (Pl. 5, fig. 7.)

Elongate; rather depressed; rufo-testaceous (immature) to piceous, appendages scarcely paler; upper surface finely alutaceous. Head very elongate; eyes rather large but less prominent than usual in genus; antennæ slender, middle joints about three times as long as wide; mentum at middle of emargination with a long slender tooth, pointed or very narrowly truncate at apex. Prothorax (by measurement) as long as wide, but appearing longer; sides rather widely reflexed; basal angles obtuse, narrowly rounded; disk with fine median longitudinal line and broad vague basal and apical transverse impressions, also with lateral impression on each side from near basal angles forward and outward to in front of middle. Elytra elongate, prolonged and independently subangulate apically; margin broadly, slightly sinuate near apex; striæ entire, rather deep, impunctate ; intervals slightly convex, third with three inconspicuous punctures. Inner wings vestigial; metepisterna short. Tibiæ not canaliculate externally; tarsi sulcate, sulci widely separated, fifth joint not ciliate, fourth not lobed externally on middle and hind feet; male anterior tarsi slightly dilated. Length $13-15 \mathrm{~mm}$.

Holotype of (Museum of Comparative Zoölogy no. 19515) from Cinchona, Jamaica, 5,000 ft., Jan. 1912, C. T. Brues; 
2 ( $\delta$ $ᄋ$ ) paratypes from the same locality, Feb. 27, 1911 (American Museum).

This species is allied to the Central American Colpodes championi Bates, eueides Bates, and especially severus Chd., of which last there is a single specimen from Guatemala in the Museum of Comparative Zoölogy. C. macer differs from all of them in its more slender form, more prolonged elytral apices, more elongate head, and more widely reflexed prothoracic margins.

Colpodes vagepunctatus $n$. sp.

Moderately broad, rather depressed; surface not strongly shining, with inconspicuous silky texture; rufo-piceous, without metallic lustre, legs not paler, antennæ dark rufous at base, testaceous with darker stripes from apex of fourth joint. Head longitudinally bi-impressed in front of eyes; mentum tooth triangular, pointed. Prothorax large, about a third wider than long (by measurement), slightly convex, slightly more narrowed in front than behind; sides more or less evenly rounded from base to apex; lateral margins moderately widely reflexed; basal angles indistinct, roundedobtuse; disk with median line fine, transverse impressions poorly defined, basal foveæ rather broad and deep, vaguely rugose, surface of disk otherwise smooth except vaguely transversely wrinkled near median line. Elytra with humeri distinct, apices sinuate and slightly produced, sutural angle right; striæ rather deep, slightly irregular but not distinctly punctate; intervals slightly convex; anterior dorsal puncture on third stria about basal fifth, second and third punctures on third interval near middle and apical fourth, slightly variable, second tending to be nearer second stria, third nearer third. Tibiæ not sulcate externally ; front tarsi with indistinct sulci each side above, hind tarsi sulcate each side; fourth joint hind tarsus strongly lobed externally, fifth joint not ciliate. Metepisterna long; inner wings reduced, about half elytral length (possibly variable). Length $\pm 12 \mathrm{~mm}$.

Holotype $q$ (United States National Museum) and 1 
damaged $q$ paratype (Museum of Comparative Zoölogy no. 19516) from Jamaica, H. G. Hubbard.

In Chaudoir's key (l. c.) this species runs to page 284, the first $z$, and falls between $o$ and $o o$, fitting neither. It differs from all structurally comparable species under both parts of the couplet in the entire absence of metallic lustre. It is not like any of the species described in "Biologia."

\section{Colpodes fractilinea $\mathrm{n}$. sp.}

Moderately broad; very shining; rufo-piceous, without metallic lustre, femora scarcely paler, tibiæ rufo-testaceous, antennæ and tarsi testaceous. Head longitudinally bi-impressed in front of eyes; mentum tooth rounded-triangular. Prothorax large, nearly a half wider than long (by measurement), slightly convex, somewhat narrower in front than behind; sides nearly evenly rounded; lateral margins moderate, reflexed; basal angles obtuse but distinct; disk with median line fine, transverse impressions poorly marked, basal foveæ rather broad, moderately deep; surface smooth. Elytra with humeri distinct; apices slightly produced, independently irregularly rounded; striæ fine, especially externally, and interrupted to form series of more or less elongate impressed lines; scutellar stria long, better impressed; intervals flat; anterior dorsal puncture on third stria near basal fifth, second and third punctures on second stria near middle and apical fourth. Tibiæ not sulcate externally; front tarsi not sulcate above; hind tarsi sulcate on outer side, not distinctly so on inner; fourth joint hind tarsus bilobed but only slightly more produced externally than internally; fifth joint not ciliate. Metepisterna long; inner wings not reduced. Length just over $9 \mathrm{~mm}$.

Holotype of (United States National Museum) from Diquini, Haiti, J. B. Ferris ; unique.

In Chaudoir's table (l. c.) this species runs to page 282, "III, 2, b" (C. aphædrus etc.). The lack of metallic lustre alone is enough to distinguish it from most of the species of this group, and the interrupted elytral striæ are different from those of any species of the aphrdrus group listed by Chaudoir. 


\section{Colpodes sp.}

The only Colpodes I have seen from Cuba is a single specimen of an undetermined species (briefly characterized in my key ) from Somorrostro, (Havana), coll. Barro.

Glyptolenus simplicicollis n. sp

Piceous brown, abdomen, epipleurae, and appendages rufescent. Head bi-impressed between front margins of eyes; eyes large but not very prominent; front smooth. Prothorax subquadrate, only slightly wider than long (by measurement), slightly narrower in front than at base; posterior angles obtuse, preceded by a minute sinuation of the sides, which are otherwise nearly evenly, very broadly rounded throughout; lateral margins very narrow anteriorly, gradually broader and reflexed in posterior half; base truncate at middle, somewhat rounded-oblique at sides; disk with usual impressions, but without extra transverse rugae. Elytra relatively very broad, convex, rather deeply striate, striæ slightly uneven but not distinctly punctate; intervals somewhat convex, third very inconspicuously bipunctate, the punctures before basal fourth and behind middle. Metepisterna slender. Tibiæ canaliculate externally; tarsi strongly sulcate above; male tarsi slightly dilated. Length $71 / 2 \mathrm{~mm}$.

Holotype ô (American Museum) from Laudet, Dominica, June 9, 1911; unique.

This species is a Glyptolenus as the genus was used by Bates in "Biologia" (Coleop. 1, part 1, p. 98). The genus is hardly distinct from Colpodes. G. simplicicollis differs from all previously described species in the combination of non-rugulose pronotum and impunctate elytral striæ. The general appearance of the insect is much like that of a stout Anchonoderus.

53. Agonum (Anchomenus) extensicolle cubanum n. subsp. extensicollis Chev. extensicolle Gundlach (not Feronia extensicolle Say).

Head and prothorax rather bright green, but very alutaceous and not strongly shining; elytra dull brown-bronzed, 
outer edges green; base of antennæ, palpi, legs dull brown. Length $73 / 4,-9 \mathrm{~mm}$.

Cuba: holotype $\hat{\sigma}$ (Museum of Comparative Zoölogy no. 19517) and 8 paratypes from Soledad (near Cienfuegos), "Jan.-Feb." (C. T. Brues), July 1 (B. B. Leavitt), Oct. 31, Nov 11 ; 1 paratype from Marcata, Rio Bayamo (M. C. Z.) ; 2 paratypes from Baraguá, Camagüey, at light, May 3 \& 5 (L. C. Scaramuzza) and May 29 (L. D. Christenson) (United States National Museum); two discolored specimens, not types, from Cayamas, Sta. Clara, May 26 and June 1, E. A. Schwarz (U. S. N. M.) ; 1 paratype from Camagüey, "Aug.- Sept.," J. M. Osorio (Collection of Estación E. Agronómica) ; 2 discolored specimens from Baraguá, at light, Nov. 2, L. C. Scaramuzza, and Cumanayagua, Sta. Clara, June, F. de Zayas (both in Est. E. Agronómica). My specimens were taken in very coarse gravel beside the Arimao River.

The Cuban subspecies differs from true Agonum extensicolle (Say) of the eastern United States, and from practically all other forms of the species occurring on the continent north of Mexico, in having the legs infuscate, not testaceous. From Mexican specimens and others with brown legs the Cuban ones differ in the much brighter green head and prothorax.

54. Anchonoderus subtilis Bates.

55. Lachnophorus leucopterus Chev.

56. Euphorticus pubescens æneolus Bates

57. Perigona nigriceps (Dej.)

58. Perigona laevigata (Bates)

59. Perigona picea $n$. sp.

Slender (for the genus), rather convex; rufo-testaceous (immature) to piceous, elytra with faint opalescence in certain lights; head and disk of prothorax darker, mouth parts and appendages testaceous. Head: mandibles rather long, curved, acute; eyes moderately prominent; antennæ stout; mentum with a triangular tooth in emargination. 
Prothorax by actual measurement about a fourth wider than long at middle, but appearing almost as long as wide; sides not sinuate, barely convex in profile before the rounded-obtuse basal angles; disk with a fine longitudinal line but no transverse impressions, vaguely impressed each side near base. Elytra each with two inner striæ distinct except at extreme base and apex, irregularly punctulate; several outer striæ more or less faintly visible; marginal stria normal for Perigona. Length 3-4 mm.

Holotype (Museum of Comparative Zoölogy no. 19518) and 2 paratypes from Grande Rivière, Haiti, W. M. Mann; 1 paratype from Diquini, Haiti, Mann (M. C. Z.) ; 1 paratype from San Carlos Estate, Guantánamo, Cuba, Oct. 4-8 (American Museum); 1 paratype from Cayamas, Sta. Clara, Cuba, Baker (United States National Museum) ; 1 paratype from Yateras Dist., Oriente, Cuba, W. M. Mann (U. S. N. M.) ; 2 paratypes from Cuba, Poey Collection no. 645 (Philadelphia Academy of Sciences) ; 1 paratype from Santo Domingo, A. Busck (U. S. N. M.) ; 1 specimen, not a type, from Gourbeyre, Guadeloupe (American Museum).

For relationships of this species, see key below.

Perigona microps n. sp. (Pl. 5, fig. 8.)

Form average for genus; irregularly castaneous, elytra with faint opalescent lustre, suture and parts of prothorax more rufescent, mouth and appendages testaceous. Head with mandibles elongate; eyes small, not prominent, only slightly breaking the outline of sides of head; antennæ moderate, less stout than in picea; mentum with a small tooth in emargination. Prothorax about a fourth wider than long; sides oblique but scarcely or not sinuate before the obtuse but not rounded posterior angles; disk about as in picea. Elytra each with two or three inner striæ slightly impressed except at base and apex; several outer striæ suggested by faint irregularities of the surface in proper light; striæ irregular but hardly distinctly punctate. Length $\pm 31 / 4 \mathrm{~mm}$.

Puerto Rico: holotype (United States National Museum) from Bayamon, Jan.; 1 paratype (Museum of Comparative 
Zoölogy no. 19519) from Fajardo, Feb. Both specimens taken by Aug. Busck.

As compared with Perigona picea, this species is broader, less convex, with more slender antennæ, better defined prothoracic angles, less distinct elytral striæ, and especially smaller eyes. For other distinguishing characters see the following key to the West Indian species of Perigona, of which I have seen all except guadeloupensis.

1. Color chiefly testaceous, head and apices of elytra blackish; length $3 \mathrm{~mm}$. or less; cosmopolitan

nigriceps Dej. Color piceous to testaceous (immature), apices of elytra not contrastingly darker; length $3 \mathrm{~mm}$. or more

2 . Sides of prothorax sinuate before base; $31 / 2 \mathrm{~mm}$.; Guadeloupe guadeloupensis Fleut. \& Sallé Sides of prothorax not, rarely just barely, sinuate 3

3. Eyes only slightly breaking outline of sides of head (Pl. 5, fig. 8.) microps n. sp. Eyes much more prominent

4. Elytra without distinct striæ near suture; body broader, more depressed; 4-5 mm.; Cuba, Puerto Rico (and Central America) lævigata Bates. Elytra each with at least two distinct, more or less punctate striæ near suture; more slender and convex; 3-4 mm. picea n. sp.

60. Badister seclusus Blatchley.

61. Chlaenius niger ludoviciana Leng.

niger Gundlach, not Randall.

This is one of the few Carabidæ known from Cuba of which I have not seen Cuban specimens.

62. Chlaenius gundlachi Chd.

63. Chlaenius cubanus Chd. poeyi Gundlach, not Chevrolat.

64. Chlaenius perplexus Dej.

circumcinctus Say. poeyi Chev. 
65. Rembus laticollis Lec.

66. Anatrichis picea (Mots.).

67. Oodes amaroides Dej.

Recorded from Cuba by Gundlach, but I have not yet seen a Cuban specimen.

68. Stenocrepis (Crossocrepis) sulcatus Chev.

69. Stenocrepis (s. s.) insulanus (J.-Duv.)

70. Stenocrepis (s. s.) duodecimstriata (Chev.)

lecontei (Chd.).

71. Stenocrepis (Stenous) tibialis (Chev.)

femoralis (Chd.).

pallipes Gundlach, not Reiche.

Gundlach's short description evidently applies to this species rather than to the true S. pallipes (Reiche) of South America.

72. Stenocrepis (Stenous) metallicus (Dej.)

Stenocrepis (Stenous) subdepressus n. sp.

Of usual form for Stenous, but less convex; black, with greenish or bluish green lustre, head and margins of body scarcely brighter; legs entirely piceous or rufo-piceous, antennæ piceous with three basal joints rufescent. Head shining, nearly impunctate, but with excèedingly fine, rather sparse punctuation; mentum tooth long and acute. Prothorax moderately narrowed in front, slightly behind; sides scarcely sinuate before the right or slightly obtuse basal angles; disk rather strongly flattened basally, finely alutaceous. Elytra each with seven fine, slightly abbreviated, impunctate striæ, seventh finer than others; scutellar stria distinct; intervals flat, finely alutaceous but somewhat shining, third impunctate. Front tarsi of male rather widely dilated, about as in S. metallicus Dej. Length $\pm 81 / 2 \mathrm{~mm}$.

Holotype $\hat{\sigma}$ (Museum of Comparative Zoölogy no. 19520) and 2 ( $q$ q ) paratypes from Grande Rivière, Haiti, W. M. Mann. 
In Chaudoir's monograph of Stenous (Ann. Soc. Ent. France (6) 2, 1882, pp. 497-) this species runs to metallicus Dej., which it resembles in most points of structure, but in addition to being a broader and flatter insect, $s u b$ depressus is differently colored and has the head practically impunctate, the prothorax slightly more narrowed posteriorly, and the third elytral interval without dorsal punctures The bluish green, almost uniform coloration and slightly depressed form are strongly suggestive of some Selenophorus.

\section{Stenomorphus manni n. sp.}

Elongate, parallel, moderately convex; shining rufo-testaceous to piceous brown, lower surface and appendages slightly more rufescent. Head with two rather small, abrupt foveae anteriorly; front smooth. Prothorax elongate in male (about five-eighths as long as elytra), less elongate in female; widest just behind middle; sides parallel ( $q$ ) or very slightly converging ( $\delta$ ) anteriorly, somewhat contracted. and broadly but slightly sinuate before the rounded basal angles; disk with fine median line and oblique linear basal foveae, also with faint transverse undulate strigæ, surface not punctate. Elytra somewhat emarginate at base; striæ deep and impunctate; intervals convex, third with a series of punctures on inner edge, fifth with six or fewer irregular punctures either at middle or near edges. Sexual tarsal characters as usual in genus; male middle femora only minutely denticulate on lower edge near apex; middle tibiæ straight in both sexes; hind tarsi slender. Length \pm 12 ( o ) -15 ( $\delta$ ) $\mathrm{mm}$.

Holotype ô (Museum of Comparative Zoölogy no. 19525)

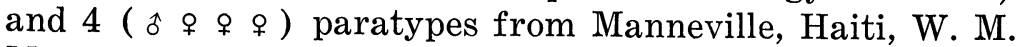
Mann.

This, the first Stenomorphus to be found in the West Indies, is very close to rufipes Lec. of the United States but is slightly more slender, with the middle femora of the male more minutely denticulate and the male middle tibiæ not even slightly arcuate as they are in rufipes.

73. Gynandropus subquadratus Putz. 


\section{Key to West Indian SELENophorus}

The following brief and rather artificial key includes chiefly species which I have seen myself. Three other species, marked with asterisks, are merely inserted in the proper places from description, without final distinguishing characters being given. Of species recorded from the West Indies I have been unable to place only Selenophorus lucidus Dej., described as probably from the Antilles, (near discopunctatus), and subaeneus Reiche, not known from north of Guadeloupe (probably also near discopunctatus). I have been aided in my identifications in this difficult genus by brief notes on some of Putzeys' types from Mr. A. d'Orchymont, and by comparison of specimens with the type of S. integer (Fab.) made for me by Dr. Joseph Bequaert.

1. Elytra with series of distinct punctures on second, fifth, and seventh striæ

Elytra without seriate punctures nonseriatus n. sp.

2. Surface of elytra entirely pubescent; 7-8 $\mathrm{mm}$.

pubifer Putz.

Most of elytral surface glabrous

3. Elytra dark, shining, with bluish, greenish, or cupreous iridescence

Elytra without iridescence

4. Basal foveae of prothorax impunctate or nearly so ......5 Basal foveae of prothorax rather closely, though not coarsely, punctate

5. Seventh elytral interval near apex greatly swollen laterally, overhanging margin at sinuation; $\pm 10 \mathrm{~mm}$.

carniger Putz.

Seventh interval not swollen; 7-8 $\mathrm{mm}$.

flavilabris Dej.

6. Length over $7 \mathrm{~mm}$.

Length under $7 \mathrm{~mm}$. 
7. Sides of prothorax parallel, scarcely arcuate; elytral striæ punctulate integer Fab. Sides of prothorax more arcuate; striæ not punctulate. chalybeus Dej. (and) propinquus Putz. (and) puertoricensis Mutchler.

8. Elytral striæ punctulate. striatopunctatus Putz. Elytral striæ not punctulate puncticollis Putz.

9. Surface of elytra not alutaceous....... (refer back to) 5 Surface of elytra alutaceous

10. Color rufous with elytral intervals no. 2 to 5 or 6 blackish

Color above nearly uniform

11. Male with basal angles of prothorax slightly prominent posteriorly. thoracicus Putz. Male with posterior angles of prothorax obtusely rounded, like female ................................. cinctus Putz. and (doubtfully Antillean) *dubius Putz.

12. Front shining, not alutaceous 13

Front finely but distinctly alutaceous 15

13. Basal foveæ of prothorax not distinctly punctate; $41 / 2$ $\mathrm{mm}$. parvus n. sp.

Basal foveæ of prothorax extensively punctate.

14. Form relatively broad, less convex; less shining; just over $5 \mathrm{~mm}$.; Cuba solitarius $\mathrm{n}$. sp. Narrower and much more convex; head and pronotum highly shining; just under $5 \mathrm{~mm}$.; Haiti

haitianus n. sp.

15. Basal angles of prothorax right; seriate punctures of elytra much larger than usual

Basal angles of prothorax broadly rounded; seriate punctures small

16. Length $\pm 8-9 \mathrm{~mm}$. pyritosus Dej. Length under $8 \mathrm{~mm}$. alternans Dej. 
17. Margins of elytra excised near apex; 41/2-51/2 mm. sinuatus Gyll. (and) *mundus Putz. and (doubtfully Antillean) *parumpunctatus Dej. Elytra only slightly sinuate near apex; $6 \mathrm{~mm}$. and over

18. Base of prothorax alutaceous and irregularly punctate; 6-8 $\mathrm{mm}$. discopunctatus Dej. Base of prothorax alutaceous but not punctate 19

19. Color dull blue; $\pm 111 / 2 \mathrm{~mm}$. cyaneopacus $\mathrm{n}$. $\mathrm{sp}$. Greenish, cupreous, or æneous; not over $8 \mathrm{~mm}$.

20. Prothorax rather strongly narrowed posteriorly; 7-8 $\mathrm{mm}$. beauvoisi Dej. Prothorax not distinctly narrowed posteriorly; $\pm 6 \mathrm{~mm}$. latior n. sp.

74. Selenophorus pyritosus Dej.

75. Selenophorus alternans Dej.

76. Selenophorus cinctus Putz. Selenophorus thoracicus Putz. ( 우) excisus Putz. (o )

I have seen twelve males and six females of this Haitian species and am convinced that the differences supposed by Putzeys to separate his two species are merely sexual.

77. Selenophorus flavilabris Dej.

78. Selenophorus sinuatus (Gyll.) parumpunctatus Chev., \& Gundlach, not Dej.

79. Selenophorus discopunctatus Dej. cuprinus Dej.

80. Selenophorus striatopunctatus Putz.

Selenophorus parvus n. sp.

Form average, not especially convex; blackish, scarcely æneous; appendages testaceous. Head with front shining, not alutaceous; mandibular scrobes short. Prothorax about a half wider than long (by measurement), rather strongly narrowed posteriorly; basal angles obtuse, rather narrowly 
rounded; longitudinal impressed line fine but distinct, transverse lines obsolete; disk faintly alutaceous only in region of basal foveæ, which are impunctate. Elytra with humeri not strongly angulate; striæ moderate, impunctate except for small serial punctures on second, fifth, and seventh; scutellar stria practically absent; margin slightly sinuate near apex; intervals alutaceous, glabrous. Apex of prosternum not margined. Hind tarsi slender. Male with front and middle tarsi slightly dilated and biseriately squamulose below. Length $41 / 2 \mathrm{~mm}$.

Holotype $\hat{\alpha}$ (Museum of Comparative Zoölogy no. 19523) from Coamo Springs, Puerto Rico, Sept. 28, 1929, S. T. Danforth; unique.

This species somewhat resembles a small $S$. sinuatus (Gyll.), but has much less incised elytral apices, better defined angles of prothorax, and differs in other ways.

\section{Selenophorus solitarius n. sp.}

Moderately stout and convex; greenish or æneous black, nor iridescent; appendages testaceous. Head with front impunctate, not distinctly alutaceous (except faintly posteriorly); mandibular scrobes short. Prothorax about a half wider than long (by measurement), rather strongly narrowed behind; basal angles broadly rounded; median longitudinal line distinct, anterior transverse impression faint, posterior absent; disk moderately convex, rather shining; basal foveæ alutaceous and rather closely and coarsely punctate. Elytra with humeri angulate; striæ moderate, not punctate except for moderate serial punctures on usual striæ; scutellar stria present; margin broadly, moderately sinuate near apex; intervals alutaceous, glabrous. Apex of prosternum not margined. Posterior tarsi rather long. Male with front and middle tarsi slightly dilated and biseriately squamulose. Length $\pm 51 / 2 \mathrm{~mm}$.

Holotype $\hat{o}$ (American Museum) from Zaza del Medio, Cuba, Sept. 3, 1913; 1 \& paratype (United States National Museum) from Cayamas, Sta. Clara, Cuba, Jan. 14, E. A. Schwarz. 
Superficially this species is rather like a small, stout beauvoisi Dej., but is easily separable as shown in the key.

Selenophorus haitianus n. sp.

Not especially broad, but very convex; piceous without distinct metallic or iridescent lustre; appendages testaceous. Head with front impunctate, very shining; mandibular scrobes short. Prothorax slightly less than a half wider than long (by measurement), rather strongly narrowed posteriorly; basal angles obtuse, narrowly rounded; median impressed line fine but distinct, transverse impressions obsolete; disk convex, very shining; base, especially basal foveæ, rather finely and closely punctate (punctures fainter at middle of base.) Elytra with humeri angulate; striæ moderately impressed, impunctate except for usual small serial punctures; scutellar stria present; margin moderately sinuate near apex; intervals alutaceous, glabrous. Apex of pronotum not margined. Hind tarsi long. Length $\pm 5 \mathrm{~mm}$.

Holotype \& (Museum of Comparative Zoölogy no. 19524) from Manneville, Haiti, W. M. Mann; 1 \& paratype (American Museum) from Pont Beudet, Haiti, March 3-4, 1922, altitude about $100 \mathrm{ft}$.

As compared with its closest relatives, which seem to be latior and parvus, this species differs not only as shown in the key, but in its much more convex and more shining (though not metallic) anterior parts.

\section{Selenophorus chalybeus Dej.}

Selenophorus cyaneopacus $n$. sp.

Subdepressed; bluish or purplish black, dull, not shining; legs piceous; labrum, palpi, and antennæ rufo-piceous to rufous. Head: mandibular scrobe reaching about to apex of labrum; labrum very deeply emarginate in front; bottom of emargination would be acute if angle were not narrowly rounded; antennæ moderate, not quite reaching base of prothorax; front finely alutaceous. Prothorax large, just under a half wider than long, subquadrate, slightly narrowed behind; basal angles broadly rounded; margin rather strong at sides, less so basally; disk finely alutaceous, depressed 
near basal angles, base finely and inconspicuously wrinkled, not obviously punctate. Elytra finely striate, striæ not distinctly punctate except for minute serial punctures on second, fifth, and seventh; scutellar stria rather long; intervals flat, alutaceous, but without evident punctuation; humeri distinct; subapical sinuation of margin slight. Posterior tarsi long. Prosternum not margined at apex. Male with front tarsi rather narrow; first joint longer but not wider than second, spinulose but not squamulose beneath; joints two to four distinctly but narrowly squamulose; middle tarsi almost without sexual clothing; hind tibiæ straight; middle tibiæ nearly straight, only slightly arcuate. Length $111 / 2 \mathrm{~mm}$.

Haiti : holotype of (Museum of Comparative Zoölogy no. 19526) from Cap Haitien, W. M. Mann; 3 paratypes (추 \& ) from Jean Rabel, Feb., E. C. \& G. M. Leonard (United States National Museum); 1 \& paratype from Port-au-Prince, Aug., G. N. Wolcott (U. S. N. M.).

The outstanding structural characters of this Selenophorus are the deep emargination of the labrum, deeper than in any other species I have seen, and the reduced squamulation of the male tarsi. The emargination of the labrum is said by Putzeys (Ent. Zeit. Stettiner 1878, Vol. 39, p. 4) to be variable in this genus and to reach its greatest development in S. batesi Putz., which is otherwise quite different from the present species. Bates, in "Biologia" ( $p$. 274), under S. hepburni, comments on the reduction of the squammules of the male tarsi in some Selenophorus. $\mathrm{He}$ found the character usually associated with arcuation of the male middle tibiæ, but in the present species the tibiæ are no more arcuate than in $S$. chalybeus Dej. The new species probably has a superficial resemblence to anceps Putz. and opacus Putz., of the Argentine and Brazil respectively, and to one or two other species, but differs, to judge from descriptions, not only in minor details but in having the labrum much more emarginate. It is a rather atypical Selenophorus, but cannot be referred to any other genus at present described. 


\section{Selenophorus latior n. sp.}

Rather stout, not especially convex; brownish black, not iridescent and without evident metallic lustre; appendages rufo-testaceous, antennæ darker. Head with front impunctate but finely alutaceous; madibular scrobes short. Prothorax about a half wider than long (by measurement), scarcely narrowed posteriorly, so that it appears unusually wide; basal angles rounded but not especially broadly so; median line distinct, transverse impressions obsolete; disk alutaceous, more obviously so in basal foveæ, in which there are very indistinct traces of punctuation. Elytra with humeri angulate; striæ moderate, inpunctate except for rather small serial punctures on usual striæ; scutellar stria present; margin only slightly sinuate before apex; intervals alutaceous, glabrous. Apex of prosternum not margined. Hind tarsi rather long. Male with front and middle tarsi moderately dilated and biseriately squamulose below. Length $\pm 6 \mathrm{~mm}$.

Holotype ô (American Museum) from Haina, Santo Domingo, G. N. Wolcott; 1 \& paratype (United States National Museum) from Pt. Congrejos, Puerto Rico, Feb. 8, 1920 , G. N. Wolcott.

This species is easily recognized by the unusual width of the prothorax at base, as well as by other characters given in the key.

Selenophorus nonseriatus $\mathrm{n}$. sp.

Convex, glabrous, shining; blackish, with more or less strong elytral iridescence; appendages, labrum, and tip of last ventral testaceous; mandibles, elytral suture and lateral margins (very narrowly) somewhat rufescent. Head shining, finely bi-impressed in front; antennæ rather stout; mandibular scrobes moderate. Prothorax subcordate, about a half wider than long; sides rounded anteriorly, broadly but slightly sinuate before the obtuse but distinct basal angles; lateral margin narrow; disk with transverse impressions and basal foveæ vague, median line distinct, surface impunctate. Elytra with striæ entire, moderately deep, faint- 
ly irregular but not distinctly punctate; humeri subangulate; margin near apex barely sinuate; serial punctures of second, fifth, and seventh striæ absent. Prosternum not margined. Male front and middle tarsi slightly dilated, biseriately squammulose; first joint of front tarsus not larger than second; hind tarsi short, joints three and four scarcely or not longer than wide. Last ventral narrowly emarginate at apex ( $\hat{o})$ or not ( $q$ ), also sinuately emarginate each side (both sexes). Length $\pm 51 / 2 \mathrm{~mm}$.

Holotype of (United States National Museum) and 2 ( $q$ q ) paratypes ( 1 in Museum of Comparative Zoölogy, no. 19528) from San Francisco Mts., Santo Domingo, Sept. 14 and "Sept.", A. Busck; 1 ô paratype from Claremont, Jamaica, March 14 (American Museum).

The genus to which this species should be referred is doubtful. However, it is a nearly typical Selenophorus except for the absence of the usual series of elytral punctures, and it seems better to place it in this genus temporarily rather than to describe a new genus in this difficult tribe without a complete generic revision. Superficially, except for its completely striate elytra, the new species rather resembles Bradycellus obsoletus Say of Mexico, but it differs greatly in microscopic structure.

\section{Bradycellus (Stenocellus) festinans Csy. 84. Bradycellus (Stenocellus) cubanus $n$. sp.}

Elongate, not very convex (about as in Stenocellus rupestris Say) ; irregular rufous to rufescent piceous, suture and outer margins of elytra paler ; legs and mouth parts testaceous; antennæ brown with two basal joints paler. Head rather short and broad, eyes rather prominent; front normal for rupestris group, indistinctly bifoveate between anterior edges of eyes, with a short, oblique impressed line from inner edge of eye to fovea; front also with median puncture; mentum toothed. Prothorax about three tenths wider than long, narrowed behind, with basal angles very obtuse and not even minutely prominent, but not rounded; disk with strong median longitudinal and subobsolete transverse impressions; basal foveæ broad and shallow, finely 
alutaceous and with numerous rather coarse punctures. Elytra subparallel, evenly conjointly rounded at apex; striæ entire, moderately impressed, impunctate; no scutellar stria ; intervals slightly convex, very shining, without trace of alutaceous microsculpture; one dorsal puncture on each third interval about a third from apex. Male tarsi slightly dilated, sparingly biseriately squamulose below. Length $31 / 2-41 / 2$ $\mathrm{mm}$.

Holotype o (United States National Museum) from Cayamas, Sta. Clara, Cuba, Dec. 26, E. A. Schwarz; 1 \& paratype (Museum of Comparative Zoölogy no. 19529) from the same locality, Baker; 1 \& paratype from Cumanayagua, Cuba, June 13, F. de Zayas (collection Estación E. Agronómica, Cuba); 1 specimen in poor condition from Cuba, Poey Collection no. 569 (Philadelphia Academy of Sciences).

This species belongs to the difficult rupestris group of Stenocellus. It differs from rupestris and the latter's closest relatives in having the basal angles of the prothorax not minutely prominent; from congener Lec., nubifer Lec., ventraiis Lec. (types of all three seen), and flohri Bates (series seen) in lacking the fine, transverse, alutaceous microsculpture of the elytra; and from festinans Csy. in being broader, less convex, with shallower elytral striæ and less rounded prothoracic angles.

The presence or absence of microsculpture on the elytra is apparently a constant specific character in this genus. For instance, it is uniformly present in a series of 26 specimens of congener Lec. from Brownsville, Tex., is uniformly present also in the 9 specimens of the following new species, and is uniformly undetectable in a series of 8 specimens of the Mexican nigrellus Bates which I have seen. I do not know of any species in which the sculpture varies in specimens from a single locality.

\section{Bradycellus (Stenocellus) velatus $n . s p$.}

Piceous, more rufescent below; suture and mouth always and base of elytra and humeri and (vaguely) prothorax sometimes rufescent; apex and side margins of elytra posteriorly and epipleuræ and side margins of prothorax below 
more or less testaceous; appendages pale testaceous. Head with a deep, oblique impressed line running forward from the inner margin of each eye; eyes rather prominent; front faintly alutaceous, with faint puncture at middle; mentum toothed. Prothorax rather subcordate, about a quarter wider than long; basal angles obtuse but distinct, preceded by a slight sinuation of the sides; basal foveæ broad and vague, distinctly but variably punctate; disk with median line distinct, transverse impressions sub-obsolete, surface with faint silky alutaceous lustre. Elytra parallel, evenly conjointly rounded at apex; scutellar stria absent, striation otherwise complete, regular, impunctate; intervals slightly convex, faintly alutaceous, third with a puncture near second stria behind middle. Male tarsi scarcely dilated, with scanty biseriate squamulation. Length $\pm 3 \mathrm{~mm}$.

Holotype of (Museum of Comparative Zoölogy no. 19530) and 8 paratypes from Soledad (near Cienfuegos) Cuba, June, Oct. 25-Nov. 23, some taken in flood debris; 1 specimen in poor condition from Cuba, Poey Collection no. 597 (Philadelphia Academy of Sciences) ; 2 paratypes from Rio Piedras, Puerto Rico, Sept. 8 and July, coll. by Alsina (1 returned to S. T. Danforth).

This species is very similar to Bradycellus tantillus (Dej.) of the United States, but differs (as shown by comparison with specimens of tantillus in the Leconte Collection and with a series from Florida in my own collection) in being slightly broader, less shining, and with better defined posterior thoracic angles. It is even closer to B. nigrellus Bates of Mexico and Guatemala, of which there is a series of cotypes in the Museum of Comparative Zoölogy, but differs in its uniformly duller lustre.

\section{Acupalpus (Stenolophus) ochropezus (Say).}

\section{Acupalpus (Stenolophus) convexulus $n$. sp.}

Convex, moderately shining; nearly uniform piceous black; mouth parts, two basal joints of antennæ, and legs testaceous; outer joints of antennæ (last four missing) brown. Head short, broad, with moderately prominent eyes, 
frontal sulci subobsolete; front with distinct median puncture; mentum without tooth. Prothorax very convex, not depressed at sides, just over a third wider than long (by measurement); lateral margins narrow; basal angles strongly but somewhat obtusely rounded; disk with impressed lines faint; basal foveæ vague and shallow, impunctate. Elytra convex, rather short, subparallel, evenly conjointly rounded apically; striæ rather fine, impunctate; scutellar stria moderately long, slightly impressed; intervals faintly convex; one discal puncture nearly on second stria about a fourth from apex. Length $31 / 2 \mathrm{~mm}$.

Holotype $\&$ (United States National Museum) from Baraguá, Camagüey, Cuba, June 5, 1932, at light, L. D. Christenson; unique.

Without the male it is impossible to be absolutely sure of the genus in which this species should be placed, but all nonsexual characters as well as the general appearance of the insect are as in Stenolophus. Among the North American species of the latter, the Cuban one is most like conjunctus (Say) but is much more convex, with a more transverse, differently shaped prothorax.

88. Agonoderus infuscatus Dej.

89. Masoreus (Macracanthus) brevicillus Chev. brevicollis Leng \& Mutchler (err.)

90. Masoreus (Aephnidius) ciliatus Mutchler (Pl. 5, fig. 9)

This species is described in a supplement (p. 130) following the present paper.

91. Lebia bitæniata Chev.

92. Lebia cyanea Dej. pleurodera Chd.

93. Lebia viridis Say cyanea Chd., not Dej.

94. Lebia collaris Dej.

95. Lebia (Dianchomena) abdominalis Chd.

96. Lebia (Dianchomena) solea Hentz 


\section{Gallerucidia dimidiata Chd.}

This species, which was described from Cuba, is unknown to me.

\section{Phloeoxena plagiata $n$. sp.}

Form nearly as in following species (see fig.), very broad, depressed; head and thorax piceous black, moderately shining, but with surface finely reticulate; elytra very dull opaque blackish with narrow lateral margin and large, regular, transversely oval spot extending from near middle to near apex, and laterally to the sixth striæ, rufo-testaceous; lower surface piceous except metasterna and abdomen rufotestaceous, latter with narrow black margin; appendages rufo-testaceous. Head bi-impressed anteriorly, front with a median longitudinal puncture. Prothorax between three and four tenths wider than long; side margins rather narrow anteriorly, slightly broader posteriorly; basal angles would be right except are narrowly rounded; foveæ in angles very broad and indistinct, more alutaceous than pronotal disk. Elytra with curiously broad, shallow striæ, much as in $P$. signata (Dej.) but even less distinct; intervals slightly convex, united and slightly more prominent at apex as usual in genus; sinuation of apex less pronounced than in signata; each elytron with an ocellate puncture at extreme base of second stria, also with three dorsal setigerous punctures, the first on the third stria about a sixth from base, second and third on second stria before apical third and near apex. Length just under $5 \mathrm{~mm}$.

Holotype $\hat{o}$ (American Museum) a unique from Guantánamo, Cuba, March 3, 1914, taken in a tree, C. T. Ramsden.

The simply plagiate color pattern of this species is unique in the genus, except for the following new species.

99. Phloeoxena imitatrix n. sp. (Pl. 5, fig. 10.)

Superficially almost exactly similar to plagiata (above), which it resembles in color except that the elytral macula is smaller and the ventral surface rufous to rufo-piceous. 
Structurally, imitatrix differs in having the prothorax slightly narrower, about a fourth wider than long (by measurement), with sides of base more oblique and posterior angles more obtuse, though preceded by a slight sinuation of the sides; in having the humeri more evenly rounded; in having the elytral striæ practically obliterated, faintly indicated only in favorable light; and in lacking the anterior dorsal puncture of each elytron. The position of the puncture (about a fifth from base) is usually indicated by a faint, broad, indefinite, unpunctiform impression, without a seta. The extreme basal ocellate puncture and the two posterior pairs of setigerous punctures, about a fourth and a twelfth from apex, are present. Length $\pm 41 / 2-5 \mathrm{~mm}$.

Holotype ot (United States National Museum) and 2 ( $q$ \% ) paratypes (1 in Museum of Comparative Zoölogy, no. 19531) from Cayamas, Sta. Clara, Cuba, March 3, E. A. Schwarz; 1 paratype from Cuba, Poey Collection no. 954 (Philadelphia Academy of Sciences).

The color pattern at once distinguishes this species from all previously known ones except the preceding.

\section{Phloeoxena schwarzi n. sp.}

Broad, but less so than the two preceding species; depressed; piceous black, head and prothorax slightly shining but with reticulate microsculpture; elytra duller, opaque; below piceous, rufescent medially; appendages testaceous. Head bi-impressed anteriorly, front with median impression or puncture. Prothorax subquadrate, a quarter to a third wider than long (by measurement), sides slightly sinuate before the posterior angles, which would be right except are narrowly rounded; side margins narrow anteriorly, broader posteriorly ; basal foveæ broad but poorly defined. Elytra visibly but very shallowly striate; striæ formed as usual in genus by slight, broad undulations of the surface; each elytron with three dorsal punctures as in plagiata. Length $\pm 41 / 2-5 \mathrm{~mm}$.

Holotype $\hat{\sigma}$ (United States National Museum) and 3 ( $\delta \circ q$ ) paratypes (pair in Museum of Comparative 
Zoölogy, no. 19532) from Cayamas, Sta. Clara, Cuba, Jan. 17, Mar. 8 \& 9., E. A. Schwarz.

The lack of plagiation and the narrower form distinguish this species from the two described above; the striation of the elytra is intermediate; the form of the prothorax and presence of anterior dorsal puncture of elytra are as in plagiata. Of other described species this is apparently close only to unicolor Chd. of Mexico, which is described as having the antennæ brown with pale bases and the legs brown with reddish articulations. Antennæ and legs are clear testaceous in the Cuban species.

101. Coptodera festiva Dej.

102. Coptodera unicolor Chd.

103. Microlestes poeyi (J.-Duv.)

104. Apristus sericeus n. sp.

Piceous, silvery æneous above, appendages piceous; upper surface very heavily alutaceous, lower surface less so. Prothorax about a third wider than long (by measurement), much narrowed behind; sides sinuate before the almost right but only slightly prominent basal angles. Elytra with striæ almost entire but very broad and shallow, faintly irregular but not punctate; third stria with two large and conspicuous impressions, just before middle and near apical fourth. Length $\pm 31 / 2 \mathrm{~mm}$.

Holotype (Museum of Comparative Zoölogy no. 19533) and 7 paratypes from Soledad (near Cienfuegos) Cuba, Oct. 19, Dec. 3 ; all taken running on dry sand in the sun on the banks of the Arimao River.

This species may be distinguished from all other American Apristus by its shallow elytral striæ combined with very heavily alutaceous surface. The species is apparently unique also in the large size of the dorsal punctures of the elytra. The genus has not been known before from the West Indies.

105. Callida rubricollis Dej. elegans Chd. 
106. Callida tinctula n. sp.

Small, elytra unusually broad for genus; head and prothorax brownish rufous; elytra rufescent with dull green lustre, brighter laterally; appendages testaceous. Head with prominent eyes; front smooth, except slightly alutaceous anteriorly, with large median puncture, and with slight longitudinal strigulation at sides in front of eyes. Prothorax less than a fourth wider than long, subcordate; posterior angles right, very minutely rounded; lateral margins moderate; median impressed line strong, anterior transverse impression obsolete, posterior distinct but not strong; disk moderately transversely wrinkled, irregularly and sparsely punctate near base and apex and beside middle line. Elytra rather broad but subparallel; independently emarginate-truncate at apex, with outer angle rounded; striæ moderate, punctulate; intervals barely convex, dull and alutaceous; third interval tripunctate. Inner wings fully developed. Mesosternum not tuberculate between coxæ. Lobes of fourth tarsal joints oval, slightly narrowed at base. Last ventral of female quadripunctate each side, broadly truncate apically, slightly sinuate each side. Length $51 / 2 \mathrm{~mm}$.

Holotype $\&$ (United States National Museum) from Cayamas, Sta. Clara, Cuba, Feb. 2, E. A. Schwarz; unique.

This species is generally similar to Callida decolor Chd., described from Martinique and seen by me from Haiti, and will probably prove to have similar male tarsal squammulation, with small squammules on the first three joints of the middle tarsi. It differs from decolor in being smaller, with elytra submetallic, and with the prothorax narrow and with relatively narrower margins. It is apparently not at all close to anything known from Central America.

107. Plochionus (s. s.) pallens (Fab.)

108. Plochionus (Menidius) bicolor Notman

109. Andrewesella (Euproctus) trivittata (Lec.)

110. Apenes coriacea (Chev.) 


\section{Apenes sulcicollis (J.-Duv.)}

\section{Apenes parallela (Dej.)}

\section{Apenes (s. s.) delicata n. sp.}

Form as usual in sinuata group; rather broad, depressed; æneous black with more or less piceous tinge; elytra each with humeral spot (extending inward to about fifth stria, back about a fifth of elytral length) and together with a rather broad, undulate transverse supapical fascia yellow; appendages brownish yellow. Head with front not distinctly alutaceous, very finely and sparsely punctate, not strigulose; antennæ short, middle joints scarcely longer than wide. Prothorax about a third wider than long (by measurement) subcordate; sides briefly sinuate before the basal angles, which are minutely almost right; disk alutaceous and with very fine sparse punctuation and indistinct transverse strigulation. Elytra with striæ moderate, not punctate; scutellar stria long; intervals flat or (externally) slightly convex, heavily alutaceous; third interval with two rather broadly but shallowly impressed setigerous punctures about a fourth from base and near middle. Length $\pm 5-51 / 2 \mathrm{~mm}$.

Holotype ơ (Museum of Comparative Zoölogy no. 19534) and 3 paratypes from Soledad (near Cienfuegos) Cuba, June 27 (G. Salt), Oct. 18-Nov. 7; 3 paratypes (United States National Museum) from Cayamas, Sta. Clara, Cuba, Mar. 15, May 20, and Dec. 26, E. A. Schwarz; 1 paratype from Cuba, Poey Collection no. 822 (Philadelphia Academy of Sciences). One of my specimens was taken by sifting in woodland, another in a flooded plowed field.

This species is near sinuata Say of the United States, but is smaller, with head much less punctate. It answers rather well to the description of lunulata Chd. of Yucatan, but M. René Oberthür, who has been kind enough to compare a specimen of the Cuban species with Chaudoir's type, writes that the latter is considerably larger, with a broader thorax and more elongate humeral mark. 


\section{Apenes lata n. sp.}

Also of the sinuata group, and so similar to the preceding (delicata) that a brief comparison will be sufficient for description. The form of lata is relatively broader; color, sculpture, and marking similar. Prothorax much broader, a half or more wider than long (by measurement). Size larger, \pm 7-8 $\mathrm{mm}$.

Holotype $\hat{o}$ (American Museum) and 2 paratypes ( 1 in Museum of Comparative Zoölogy, no. 19535) from Mangrove Cay, Andros Island, Bahamas, May-June, 1917, W. M. Mann. I have also seen a specimen from Soledad (near Cienfuegos) Cuba, July 1, B. B. Leavitt, but the specimen is not at present available for description.

A specimen of this species also has been sent to M. Oberthür, who finds it different from anything in his collection. I had thought from Chaudoir's description that it might be fasciata, described without locality, but M. Oberthür writes that the type of fasciata has a more cordiform prothorax, and that the West Indian species is perfectly distinct.

Apenes lævicincta n. sp.

Form of sinuata group; head and prothorax æneous rufopiceous, ground color of elytra nearly same; elytra each with humerus, a fragmentary oblique fascia at basal third, narrow lateral margin, and common subapical transverse fascia testaceous, also with a slightly oblique transverse shining black fascia common to both elytra just in front of subapical testaceous mark, also with faint dark spotting around anterior oblique fascia and on the ninth interval; lower surface mostly piceous, appendages and middle of abdomen rufous or testaceous, base of femora slightly infuscate. Head alutaceous and finely and sparsely punctate, not strigulose; antennæ short, middle joints about as wide as long. Prothorax transverse, nearly a half wider than long (by measurement), subcordate; sides briefly sinuate before basal angles, which are minutely almost right; disk alutaceous and with fine sparse punctuation and indistinct transverse strigulation. Elytra finely striate, striæ finely punc- 
tulate, scutellar stria long; intervals nearly flat, alutaceous except in transverse black fascia which is smooth and shining, third interval with two broadly impressed punctures almost on second stria (relation to striæ probably variable) about a fourth from base and near middle. Length just over $5 \mathrm{~mm}$.

Holotype $\hat{\sigma}$ (American Museum) unique, from Port-auPrince, Haiti, about 300 ft. altitude, Apr. 8-11, 1922.

This species is at once distinguishable from all others of the sinuata group, including the two described above, and I think from all other Apenes too, by the black, shining fascia just preceding the subapical testaceous one. The alutaceous head and punctulate elytral striæ further differentiate this species from the two preceding.

\section{Eucærus insularis n. sp.}

Stout, convex; piceous, elytra with iridescent lustre; antennæ with first six joints brown, seventh vaguely bicolored, outer joints whitish; palpi and legs irregular brownish yellow, posterior femora darker. Head alutaceous, antennæ relatively stout, middle joints about three times as long as wide. Prothorax cordate, about four tenths wider than long (by measurement), sides sinuate before the obtuse but distinct posterior angles; disk alutaceous. Elytra shining, striæ rather fine, entire, not punctate; intervals barely convex; third stria with inconspicuous setigerous puncture about a fourth from base, second stria with similar punctures near middle and about a fifth from apex. Inner wings vestigial. Male with one, female with two setæ each side last ventral. Length $\pm 31 / 2 \mathrm{~mm}$.

Holotype $\&$ (Museum of Comparative Zoölogy no. 19536) from Soledad (near Cienfuegos) Cuba, June, probably taken in flood debris; 3 paratypes (United States National Museum) ( $t \circ q$ ) from Cayamas, Sta. Clara, Cuba, Jan. 17 and Mar. 11, E. A. Schwarz.

This species is very close to Eucærus varicornis Lec., of which I have seen nine specimens, including the type, from South Carolina, Georgia, Florida, Alabama, and Louisiana, but differs in having the antennæ slightly stouter, the 
posterior angles of the prothorax more distinct, and the color darker. The genus has not been known before from the West Indies.

\section{Pentagonica flavipes (Lec.)}

\section{Pentagonica nigricornis $\mathrm{n}$. sp.}

bicolor (Gundlach) (Rhombodera), not Lec.

Form as usual in Pentagonica; surface alutaceous, slightly shining; black; entire prothorax, narrow reflexed margins of elytra, and legs yellow; palpi brown; antennæ entirely black. Prothorax slightly wider than in flavipes, eight or nine tenths wider than long. Elytra moderately striate, striæ irregularly subpunctate; intervals slightly convex. Length \pm 4-5 $\mathrm{mm}$.

Holotype (Museum of Comparative Zoölogy no. 19537) and 2 paratypes from Soledad (near Cienfuegos) Cuba, Nov. $1 \& 2$; all from flood debris.

This differs from all previously described New World Pentagonica in type of coloration combined with uniformly black antennæ. It resembles picticornis Bates of Guatemala except that the antennæ (of nigricornis) are not bicolored and there is less yellow on the lateral margins of the elytra. Gundlach's notes under "Rhombodera bicolor" show that he really had this species before him.

\section{Pentagonica divisa n. sp.}

atrorufa (Gundlach) (1893, An. Soc. Espanola H. N. 22, p. 292; Rhombodera), not Reiche.

bicolor (Leng \& Mutch.) (1917, Bull. American Mus. N. H. 37, p. 195), not Lec

Form as usual in genus; head and prothorax above and below yellow testaceous, prothorax above with sides (but not margins) anteriorly faintly dusky to more or less strongly infuscate; elytra dull black with narrow pale outer margins; hind body piceous below; antennæ testaceous with first joint commonly and next three rarely slightly darker; legs testaceous. Head and prothorax as usual in genus; alu- 
taceous; prothorax seven or eight tenths wider than long. Elytra unusually deeply striate. Length $+4-41 / 2 \mathrm{~mm}$.

Puerto Rico: holotype (Museum of Comparative Zoölogy no. 19538) from Yauco, F. Delgado: paratypes from Mayagüez, S. Vicks ; Jayuya, C. Gonzales; Aguada, G. Lopez ; and Boquerón, F. Mora; all December (collection of S. T. Danforth and M. C. Z.) ; Bayamon, May 14, at light (United States National Museum).

This species resembles atrorufa Reiche (Brazil), bicolor Lec. (United States), and semifulva Bates (Central America) in color, but differs from all of them in having testaceous, not dusky, antennæ, and from the last two at least, in having deeper elytral striæ.

\section{Colliuris (Odacanthella) picta extrema Liebke} picta (Gundlach), not Chd.

118-a. C. (0.) p. suturalis (Chd.) concluda Liebke.

The American Museum possesses one specimen each of suturalis Chd. and concluda Liebke, the latter differing from the former only in that the subapical red spots of the elytra are connected across the suture. These specimens were evidently taken together, "at the foot of a Jatia fence post," between Manati and Los Canos, Guantánamo, Cuba, July 27, C. T. Ramsden. It does not seem to me worth while to recognize and name color forms of species of beetles when, as in this case, color has no geographical significance, so I suggest that concluda be reduced to synonymy. The entirely unspotted form (extrema Liebke) may possibly have geographical standing in Cuba, so it may stand for the present.

\section{Colliuris (Odacanthella) gundlachi n. sp.}

Elongate; piceous, elytra translucent apically, each with a conspicuous subapical red spot and rarely a rather small reddish mark about a third from base near outer margin; antennæ brownish, joints two and three vaguely more rufescent; middle and hind tibiæ more or less spotted or banded with whitish beyond the middle; femora pale bas- 
ally, brown apically. Head: front smooth. Prothorax about two and four tenths as long as greatest width, with usual median line, with faint traces of transverse rugæ only basally, otherwise smooth; anterior angles not at all produced. Elytra with striæ almost obliterated even in basal third, where only indistinct traces of punctate striation are visible; outer apical angles approximately right; apex sinuato-truncate. Length 61/2-8 $\mathrm{mm}$.

Holotype (Museum of Comparative Zoölogy no. 19539) and 34 paratypes from Soledad (near Cienfuegos) Cuba, June, Oct. 19-Nov. 7 ; taken in a variety of damp places.

In Liebke's recent key of Odacanthella (1930, Mitt. Zool. Mus. Berlin 15, pp. 658 -) this species runs to portoricensis Liebke, differing from tetrastigma Chd. and lioptera Bates in its nearly uniformly colored antennæ. From portoricensis, which I have seen from Puerto Rico and Haiti, gundlachi differs in its maculate tibiæ, slightly smaller size, and more nearly complete obliteration of the rugæ of the prothorax and the striæ of the elytra.

120. Colliuris (Pseudocasnonia) noah n. sp. (Pl. 5, fig. 11.)

Small, slender, convex; shining piceous, elytra sometimes speckled with black in strong light; appendages and narrow elytral margin pale testaceous. Head short; sharply, obliquely constricted behind the eyes; front smooth and shining. Prothorax rather short, slightly less than twice as long as wide, truncate anteriorly, anterior angles not at all produced; disk faintly, transversely rugose, shining and impunctate except in basal and apical transverse impressions, with distinct median longitudinal impressed line; side margins each with a single setigerous puncture just before middle. Elytra narrow, only slightly dilated behind the middle, lateral margins narrow; apices sinuato-truncate, outer apical angles obtuse, narrowly rounded; elytral surface entirely shining, not alutaceous; marginal stria deep, inner impressed striæ nearly or entirely absent, but several striæ indicated by rows of widely spaced punctures in basal third of elytron; third interval with about five, fifth and seventh with fewer, setigerous punctures. Length $\pm 5 \mathrm{~mm}$. 
Holotype (Museum of Comparative Zoölogy no. 19540) and 2 paratypes from Soledad (near Cienfuegos) Cuba, Oct. 21; all taken in floating debris during a very heavy flood.

In Liebke's table of Pseudocasnonia (l. c., 664 -) this species runs to signata Chd. which, however, has the elytra strongly ridged, not smooth as in noah. So far as I can find, the latter has no really close relatives.

\section{Leptotrachelus dorsalis (Fab.)}

I have seen no Cuban specimen of this species, which is recorded by Gundlach, however.

122. Galerita tenebricosa Klug. vetula Chev.

123. Galerita ruficollis Dej. erythrodera Brullé insularis Cast. thoracica Chev.

Galerita microcostata n. sp.

Moderately stout for genus; black, head with two small red spots between eyes, tibiæ and tarsi piceous, antennæ brownish rufous. Head rather large, with sides angulate, not directly narrowed, behind eyes; front coarsely punctate. Prothorax subquadrate, very slightly wider than long (by measurement); sides broadly sinuate before basal angles, which would be right except are narrowly rounded; disk closely punctate, median line very fine, transverse impressions sub-obsolete. Elytra very slightly narrowed basally, humeri rather distinct; each elytron with nine pairs of fine longitudinal costæ, with unpaired intermediate costæ developed externally but obsolete near suture. Inner wings present. Length $151 / 2 \mathrm{~mm}$.

Holotype ô (Museum of Comparative Zoölogy no. 19541) from Mayagüez, Puerto Rico, May 12, 1932, E. Figarella, received from $\mathrm{S}$. T. Danforth; unique.

This species is a close relative of Galerita americana (L.) of South America and the Lesser Antilles (I have seen 
nine specimens from Guadeloupe), but has the prothorax and appendages dark and the inner unpaired costæ of the elytra obsolete, not conspicuous as in americana. The two species are very similar in form.

\section{Key to the West Indian Species of Pseudaptinus}

Since I am describing several new species of Pseudaptinus and recording others from the West Indies for the first time, it seems best to publish the following key:

1. Posterior angles of prothorax basal, not prominent

(Pseudaptinus s. s.) 2

Posterior angles of prothorax before base, minutely prominent (subgenus Thalpius)

2. Body irregular testaceous and brown, head black; antennæ not sharply bicolored; length just under $5 \mathrm{~mm}$. apicalis $\mathrm{n} . \mathrm{sp}$.

Uniform piceous or black; antennæ sharply bicolored; length 5-6 $\mathrm{mm}$.

3. Side margins of prothorax distinct ... marginicollis $\mathrm{n}$. sp. Side margins of prothorax obsolete .........thaxteri $\mathrm{n}$. sp.

4. Body bicolored, black or brown with rufous prothorax; punctuation rather fine and close; $\pm 5 \mathrm{~mm}$. insularis Mutchler

Not bicolored; punctuation variable

5. Pinkish brown, upper surface opaque, finely and very closely punctate; $\pm 51 / 2 \mathrm{~mm}$. cubanus Chd. Rufous, plain brown, or black; rather closely but more coarsely punctate, surface of head and thorax rather shining between punctures

6. Antennæ slender, middle joints about twice as long as wide; elytra usually with a vague post-median dark area dorsalis Brullé Antennæ stout, middle joints scarcely longer than wide. 7 
7. Elytral striæ rather irregularly but seriately punctate except apically, the punctures much coarser than those minutely prominent pygmæus Dej. of the intervals; prothorax narrower, basal angles more Elytral striæ not evidently seriately punctate, not more coarsely punctate than intervals; prothorax broader, basal angles more broadly prominent.......deceptor n. sp.

\section{Pseudaptinus (s. s.) apicalis n. sp.}

Convex, rather elongate, finely pubescent; head piceous black; prothorax rufo-testaceous; elytra brown, vaguely paler near suture anteriorly, with about apical fifth testaceous. Head: antennæ stout; eyes rather large and prominent; front finely alutaceous; moderately punctate. Prothorax convex, comparatively little dilated apically; side margins indistinct; disk rather shining, rather closely punctate, with distinct median line, without transverse rugæ. Elytra convex, deeply striate, striæ not punctate; intervals finely alutaceous; apices obliquely subtruncate, with outer angles broadly rounded. Length just under $5 \mathrm{~mm}$.

Holotype (Museum of Comparative Zoölogy no. 19542) unique, from Soledad (near Cienfuegos) Cuba, Nov. 13.

Among described species this is close apparently only to Pseudaptinus subfasciatus Chd. of Brazil, which, however, has the elytra much more extensively pale. M. Oberthür has compared the Cuban specimen with Chaudoir's type and states that they are different species. From S. leprieuri (Buquet) of Cayenne, which must be superficially similar, apicalis differs in its non-rugose prothorax and in other ways.

\section{Pseudaptinus (s. s.) marginicollis $\mathrm{n}$. sp.}

Elongate, rather convex, finely pubescent; dull piceous black, rufescent below; antennæ with three basal joints mostly black, fourth and fifth bicolored, outer joints whitish; palpi dark, tipped with whitish; legs testaceous. Head with eyes rather large and prominent; antennæ rather slender; front alutaceous, moderately punctate. Prothorax narrow, about a fifth longer than wide (by measurement), 
but appearing longer, widest near the front; posterior angles not prominent; lateral margins distinct, narrowly raised; disk alutaceous, punctate like head, with distinct median impressed line abbreviated at base and apex. Elytra deeply, nearly evenly striate; striæ impunctate; intervals convex, alutaceous. Length 5-6 mm.

Holotype (Museum of Comparative Zoölogy no. 19543) and 9 paratypes from Soledad (near Cienfuegos) Cuba, Sept. 2 (B. B. Leavitt), June, Oct. 21, Nov. $7 \& 9$, most of the specimens from flood debris; 1 paratype from Baraguá, Cuba, Oct. 28, at light, L. C. Scaramuzza (United States National Museum).

This and the following species must be near Pseudaptinus elegans (Chd.) of Brazil, but are said by M. Oberthür, to whom I am indebted for comparisons of West Indian specimens with Chaudoir's type, to be distinct. I hope in my next paper to be able to publish the distinguishing characters. Both West Indian species, especially the one from Grenada (below) are near Ps. lecontei Dej. of the United States, too, but lecontei, of which I have seen several specimens, has the prothorax more dilated anteriorly and is more shining.

\section{Pseudaptinus (s. s.) thaxteri n. sp.}

Exceedingly similar to marginicollis. The preceding description may stand for the present species except that the side margins of the prothorax are obsolete and the color less contrasting. Length about $5 \mathrm{~mm}$.

Holotype (Museum of Comparative Zoölogy no. 19544) and 1 paratype from Grand Etang, Grenada, R. Thaxter.

This species is, of course, named in honor of the collector, the late Professor Roland Thaxter.

126. Pseudaptinus (Thalpius) cubanus (Chd.)

127. Pseudaptinus (Thalpius) insularis Mutchler.

This species is described in the American Museum (New York) Novitates no. 686, 1934, p. 4. 


\section{Pseudaptinus (Thalpius) pygmaeus (Dej.)}

129. Pseudaptinus (Thalpius) dorsalis Brullé.

130. Pseudaptinus (Thalpius) deceptor n. sp. (Pl. 5, fig. 12.)

Of average form for group; rufescent to piceous brown, appendages testaceous; entire dorsal surface finely pubescent, moderately punctate with punctures of average size; surface between punctures rather shining. Head with eyes large; antennæ short, middle joints scarcely longer than wide. Prothorax almost exactly as long as wide (by measurement), subcordate but broader at base than usual; subbasal denticles (basal angles) rather broad and conspicuous, but acute; lateral margins rather broad; disk not very convex, middle line distinct except near base and apex. Elytra rather shallowly striate, striæ not regularly punctate but with irregular punctuation like that of intervals; latter slightly convex, not rugulose. Length $\pm 5-6 \mathrm{~mm}$.

Holotype (Museum of Comparative Zoölogy no. 19545) and 55 paratypes from Soledad (near Cienfuegos) Cuba, June, Oct. 21-Nov. 7, mostly taken in flood debris.

The largest specimens of the series have the punctuation of the prothoracic episterna less developed than in smaller ones, but the variation is probably only individual. The distinguishing characters of the species are sufficiently given in the key.

\section{Zuphium cubanum Liebke.}

Described in Revista Ent., 1933, Vol. 3, p. 470.

132. Zuphium bierigi Liebke.

Described in the same paper as the preceding, p. 467. I have not seen this species; all my Cuban Zuphium are certainly cubanum.

133. Brachynus lateralis Dej.

134. Brachynus brunneus Cast. 
1934]

New West Indian Carabidæ

129

Psyche, 1934

Vol. 41, Plate 5
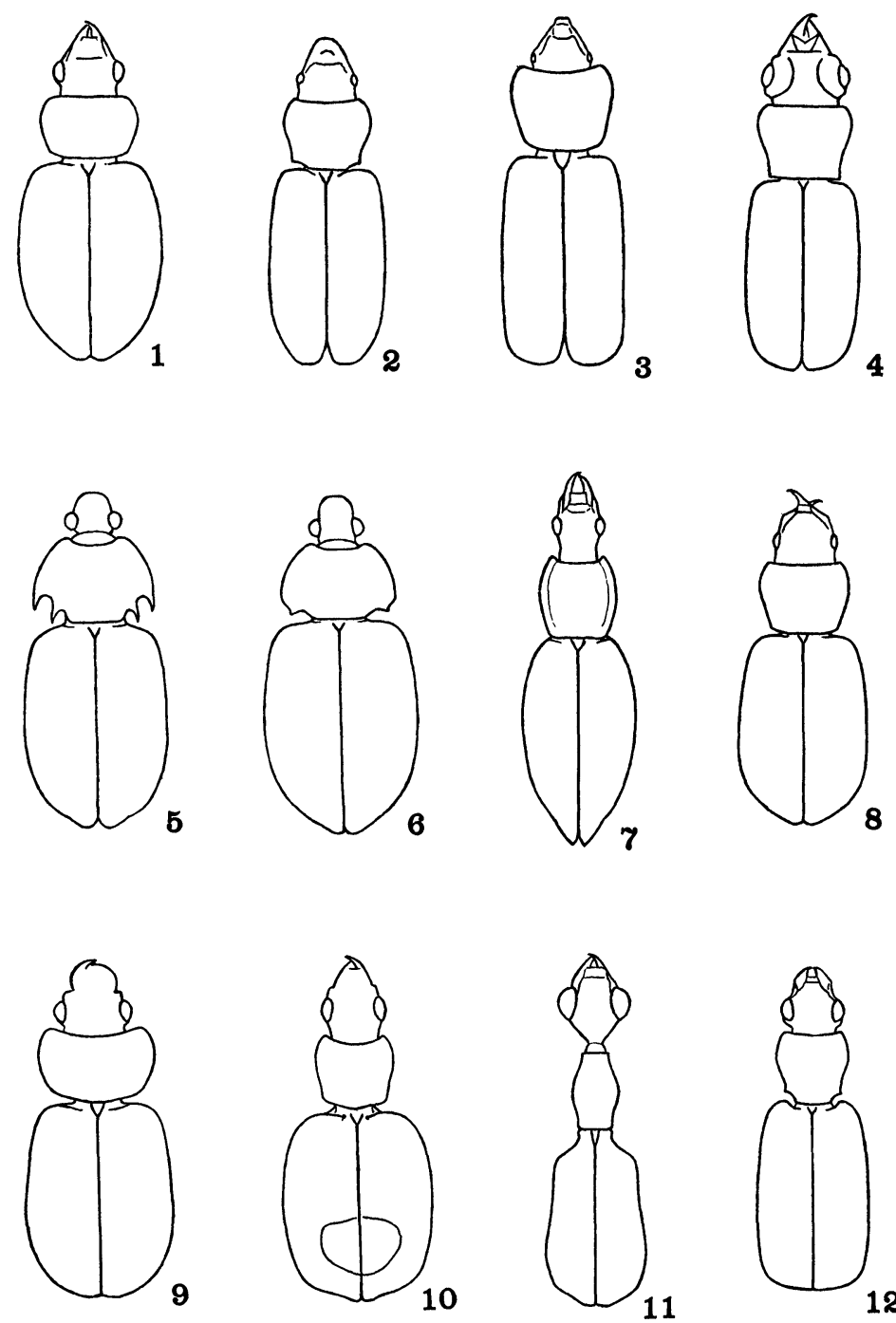

Darlington -West Indian Carabidæ 


\section{EXPLANATION OF PLATE}

Outlines (from camera-lucida drawings) of head, prothorax, and elytra of

Fig. 1.-Tachys (s. s.) dominicanus n. sp.

Fig. 2.-Limnastis americanus n. sp.

Fig. 3.-Micratopus parviceps n. sp.

Fig. 4.-Perileptus columbus n. sp.

Fig. 5.-Coptia sauricollis n. sp.

Fig. 6.-Coptia effeminata n. sp.

Fig. 7.-Colpodes macer n. sp.

Fig. 8.-Perigona microps n. sp.

Fig. 9.-Masoreus (Aephnidius) ciliatus n. sp. (Mutchler.)

Fig. 10.-Phloeoxena imitatrix n. sp.

Fig. 11.-Colliuris (Pseudocasnonia) noah n. sp.

Fig. 12.-Pseudaptinus (Thalpius) deceptor n. sp.

\section{SUPPLEMENT:}

Masoreus (Aephnidius) ciliatus new species (Mutchler) (Pl. 5, fig. 9)

Oblong oval, black, legs, antennæ and mouth parts testaceous. Head subquadrate, finely closely punctate; mandibles without setigerous punctures in the scrobes, sides elevated; basal joint of antennæ with a long bristle at apex; front of labrum slightly curved inwardly (almost straight) margin with setigerous punctures; clypeus with a puncture on each side. Pronotum subquadrate, one-third wider than long, wider than the head, widest at about the middle, apical angles narrowly rounded and slightly produced, lateral margin with a setigerous puncture on the apical third and another at the basal fifth, basal angles broadly rounded, marginal bead extending from the side of the insertion of the head to the scutellar area, a median longitudinal impressed line, somewhat well marked, extending from the apex to near the base, with indistinct oblique lines, extending backwards from this median line. Scutellum triangular, apex narrowly rounded. Elytra with humeral angles rounded margins not interrupted, surface (under high 

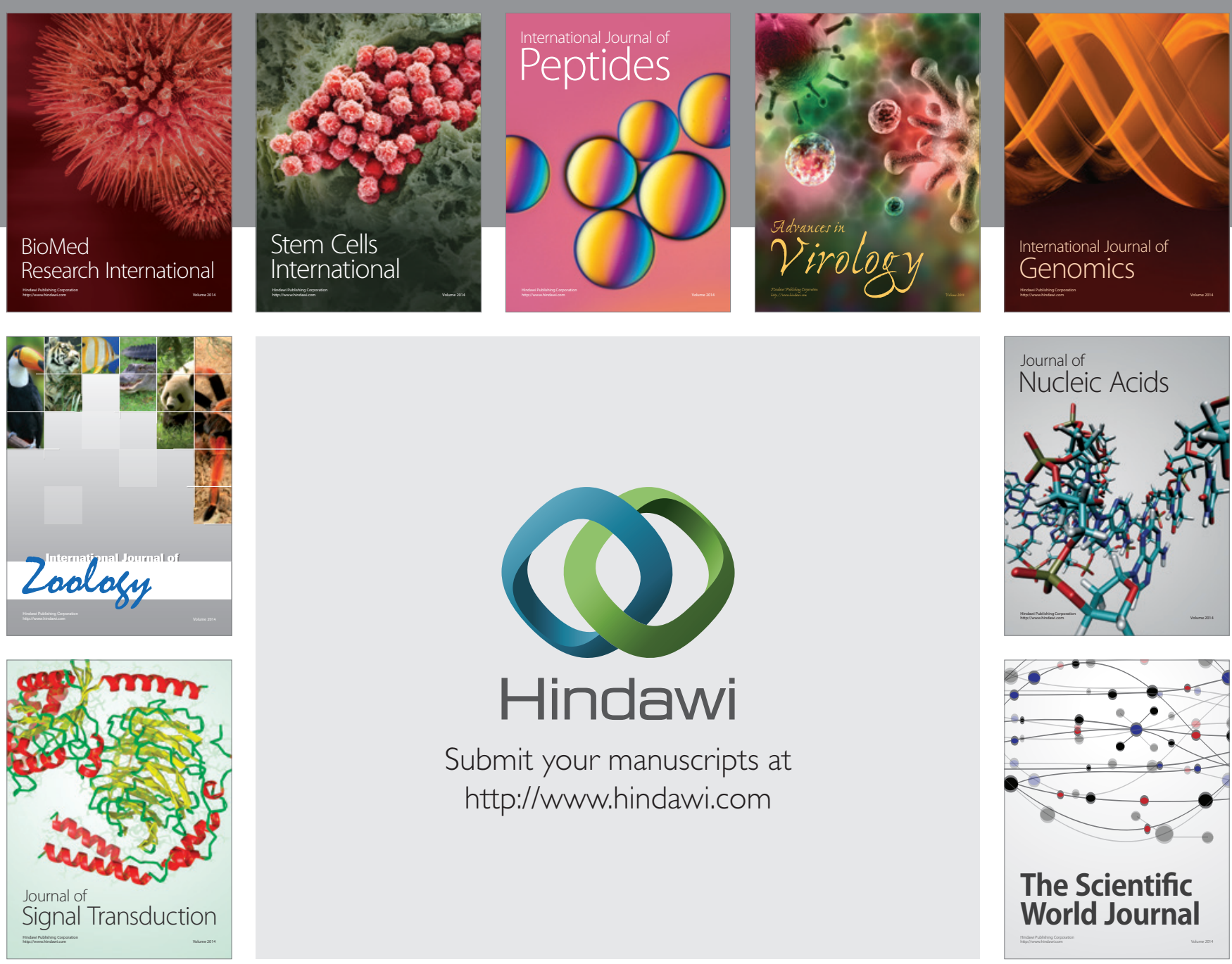

Submit your manuscripts at

http://www.hindawi.com
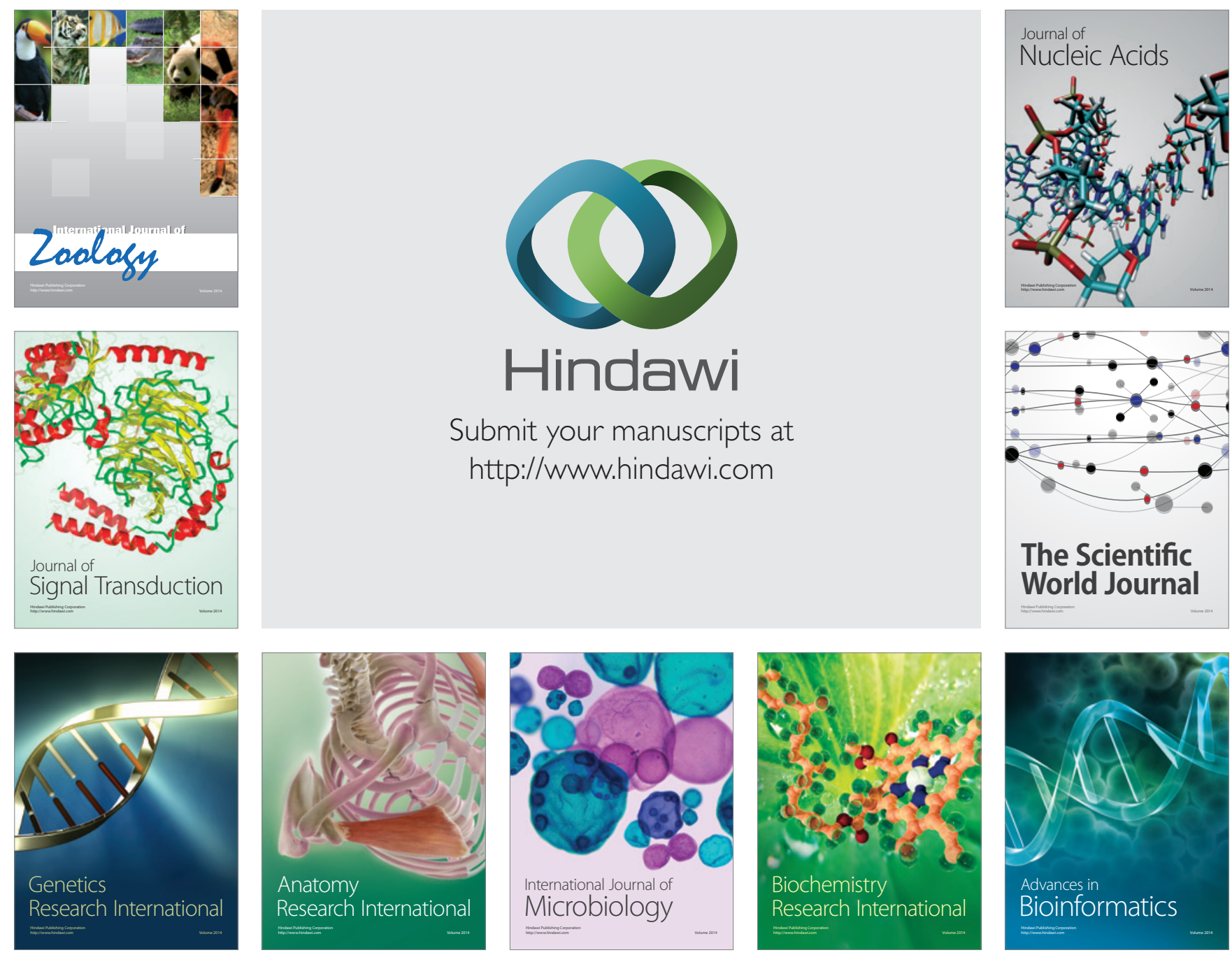

The Scientific World Journal
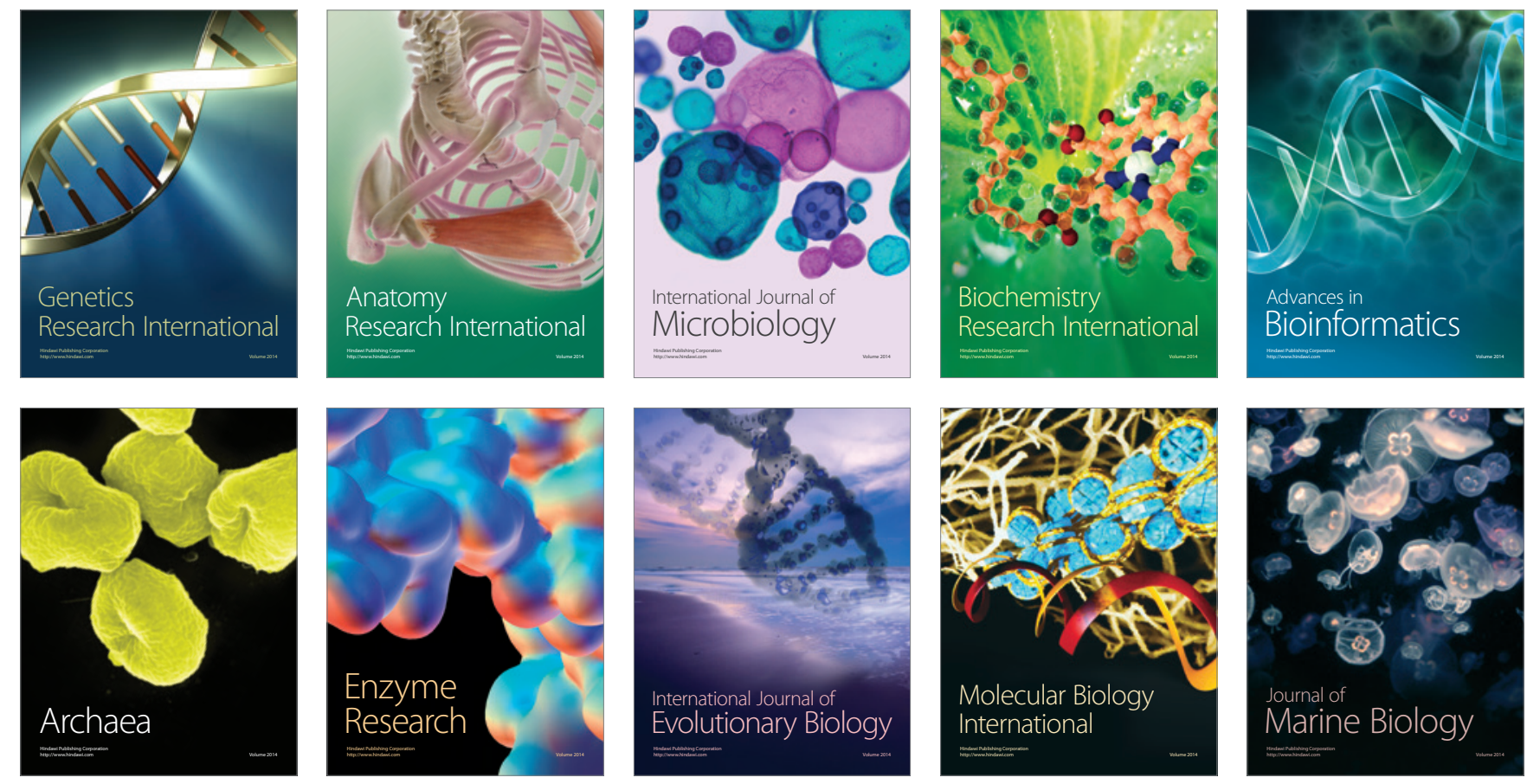